NBER WORKING PAPER SERIES

\title{
WINNERS AND LOSERS OVER TWO CENTURIES OF GLOBALIZATION
}

\author{
Jeffrey G. Williamson \\ Working Paper 9161 \\ http://www.nber.org/papers/w9161
NATIONAL BUREAU OF ECONOMIC RESEARCH
1050 Massachusetts Avenue
Cambridge, MA 02138
September 2002

Paper to be delivered as the $\mathbf{2 0 0 2}$ WIDER Annual Lecture, Copenhagen (September 5, 2002). The research
reported in this paper draws heavily on recent collaborations with Michael Clemens, John Coatsworth, Tim
Hatton, Kevin O'Rourke, and especially Peter Lindert. I am grateful to all five. I also acknowledge with
pleasure financial support from the National Science Foundation SES-0001362. The views expressed herein
are those of the authors and not necessarily those of the National Bureau of Economic Research.
(C) 2002 by Jeffrey G. Williamson. All rights reserved. Short sections of text, not to exceed two paragraphs,
may be quoted without explicit permission provided that full credit, including $\odot$ notice, is given to the source. 
Winners and Losers Over Two Centuries of Globalization

Jeffrey G. Williamson

NBER Working Paper No. 9161

September 2002

JEL No. F0, N0, O5, D3

\begin{abstract}
$\underline{\text { ABSTRACT }}$
The world has seen two globalization booms over the past two centuries, and one bust. The first global century ended with World War I and the second started at the end of World War II, while the years in between were ones of anti-global backlash. This lecture reports what we know about the winners and losers during the two global centuries, including aspects almost always ignored in modern debate - how prices of consumption goods on the expenditure side are affected, and how the economic position of the poor is influenced. It also reports two responses of the winners to the losers' complaints. Some concessions to the losers took the form of anti-global policy manifested by immigration restriction in the high-wage countries and trade restriction pretty much everywhere. Some concessions to the losers were also manifested by a "race towards the top" whereby legislation strengthened losers' safety nets and increased their sense of political participation. The lecture concludes with four lessons of history and an agenda for international economists, including more attention to the impact of globalization on commodity price structure, the causes of protection, the impact of world migration on poverty eradication, and the role of political participation in the whole process.
\end{abstract}

Jeffrey G. Williamson

Department of Economics

Harvard University and the Center for International Development

Cambridge MA 02138

and NBER

jwilliam@kuznets.fas.harvard.edu 


\section{Globalization and World Inequality}

Globalization in world commodity and factor markets has evolved in fits and starts since Columbus and de Gama sailed from Europe more than 500 years ago. This lecture begins with a survey of this history so as to place contemporary events in better perspective. It then asks whether globalization raised world inequality. This question can be split into two more: What about income gaps between nations? What about income gaps within nations? Collaborative work with Peter Lindert stresses the first question (Lindert and Williamson 2002a, 2002b), but this lecture stresses the second two, the reason being that answers to these have more relevance for policy and for the ability of a globally-integrated world to survive. Indeed, at various points in the lecture, I ask when there has been global backlash in the past - driven by complaints of the losers, and whether and how the complaints of the losers were accommodated by the winners. Finally, this lecture also stresses the contribution of world migration to poverty eradication.

Recent scholarship has documented a dramatic divergence in incomes around the globe over the past two centuries. Furthermore, all of this work shows that the divergence was driven overwhelmingly by the rise of between-nation inequality, not by the rise of inequality within nations (Berry et al. 1991; Maddison 1995; Pritchett 1997; Bourguignon and Morrisson 2000). Figure 1 uses the work of François Bourguignon and Christian Morrisson to summarize these trends, and it confirms that changing income gaps between countries explains changing world inequality. However, the fact that the rise of inequality within nations hasn't driven the secular rise in global inequality hardly implies that it has been irrelevant: policy is formed at the country level, and changing inequality within borders has often triggered policy responses. Furthermore, the absence of a net secular change in within-country inequality at the global level may simply reveal an equilibrium process whereby rising within-country inequality breeds policy responses that force the distribution back to some culturally-acceptable steady state. That level may be 
far higher for the United States than for Japan, to take two modern economic giants as examples.

I start by decomposing the centuries since 1492 into four distinct globalization epochs. Two of these were pro-global, and two were anti-global. I then explore whether the two pro-global epochs made the world more unequal, and whether it produced backlash.

\section{Making a World Economy}

\section{Epoch I Anti-Global Mercantilist Restriction 1492-1820}

The Voyages of Discovery induced a transfer of technology, plants, animals and diseases on an enormous scale, never seen before and maybe since. But the impact of Columbus and da Gama on trade, factor migration and globalization was a different matter entirely. For globalization to have an impact on relative factor prices, absolute living standards and GDP per capita, domestic relative commodity prices and/or relative endowments must be altered. True, there was a world trade boom after 1492, and the share of trade in world GDP increased markedly (O'Rourke and Williamson 2002a). But was that trade boom explained by declining trade barriers and global integration? A pro-global decline in trade barriers should have left a trail marked by falling commodity price gaps between exporting and importing trading centers, but there is absolutely no such evidence (O'Rourke and Williamson 2002b). Thus, 'discoveries' and transport productivity improvements must have been offset by trading monopoly markups, tariffs, non-tariff restrictions, wars, and pirates, all of which served in combination to choke off trade.

Since there is so much confusion in the globalization debate about its measurement, it might pay to elaborate on this point. Figure 2 (taken from O'Rourke and Williamson 2002a) presents a stylized view of post-Colombian trade between Europe and the rest of the world (the latter denoted by an asterisk). MM is the European import demand function (that is, domestic demand minus domestic supply), with import demand declining as the home market price $(p)$ increases. SS is the foreign export 
supply function (foreign supply minus foreign demand), with export supply rising as the price abroad $\left(p^{*}\right)$ increases. In the absence of transport costs, monopolies, wars, pirates, and other trade barriers, international commodity markets would be perfectly integrated: prices would be the same at home and abroad, determined by the intersection of the two schedules. Transport costs, protection, war, pirates, and monopoly drive a wedge $(\mathrm{t})$ between export and import prices: higher tariffs, transport costs, war embargoes and monopoly rents increase the wedge while lower barriers reduce it. Global commodity market integration is represented in Figure 2 by a decline in the wedge: falling transport costs, falling trading monopoly rents, falling tariffs, the suppression of pirates, or a return to peace all lead to falling import prices in both places, rising export prices in both places, an erosion of price gaps between them, and an increase in trade volumes connecting them.

The fact that trade should rise as trade barriers fall is, of course, the rationale behind using trade volumes or the share of trade in GDP as a proxy for international commodity market integration. Indeed, several authors have used Angus Maddison's (1995) data to trace out long-run trends in commodity market integration since the early nineteenth century, or even earlier (e.g. Hirst and Thompson 1996). However, Figure 2 makes it clear that global commodity market integration is not the only reason why the volume of trade, or trade's share in GDP, might increase over time. Just because we see a trade boom doesn't necessarily mean that more liberal trade policies or transport revolutions are at work. After all, outward shifts in either import demand (to MM') or export supply (to SS') could also lead to trade expansion, and such shifts could occur as a result of population growth, the settlement of previouslyunexploited frontiers, capital accumulation, technological change, a shift in post-Colombian income distribution favoring those who consume imported 'exotic' luxuries, and a variety of other factors. Thus, Figure 2 argues that the only irrefutable evidence that global commodity market integration is taking place is a decline in the international dispersion of commodity prices, or what I call commodity price convergence. However, we cannot find it (O’Rourke and Williamson 2002b). 
If it wasn't declining trade barriers that explains the world trade boom after Columbus, what was it? Just like world experience from the 1950s to the 1980s (Baier and Bergstrand 2001), it appears that European income growth -- or growth of incomes of the landed rich -- might have explained as much as two thirds of the trade boom over the three centuries as a whole (O'Rourke and Williamson 2002a). ${ }^{1}$ The world trade boom after Columbus would have been a lot bigger without those anti-global interventions. And labor migration and capital flows were, of course, only a trickle.

\section{Epoch II The First Global Century 1820-1913}

The 1820 s were a watershed in the evolution of the world economy. International commodity price convergence did not start until then. Powerful and epochal shifts towards liberal policy (e.g. dismantling mercantilism) were manifested during that decade. In addition, the 1820 s coincide with the peacetime recovery from the Napoleonic wars on the Continent, launching a century of global pax Britannica. In short, the 1820 s mark the start of a world regime of globalization.

Transport costs dropped very fast in the century prior to World War I. These globalization forces were powerful in the Atlantic economy, but they were partially offset by a rising tide of protection. Declining transport costs accounted for two-thirds of the integration of world commodity markets over the century following 1820, and for all of world commodity market integration in the four decades after 1870, when globalization backlash offset some of it (Lindert and Williamson 2002a). The political backlash of the late nineteenth century and interwar period was absent in Asia and Africa -- partly because these regions contained colonies of free trading European countries, partly because of the power of gunboat diplomacy, and partly because of the political influence wielded by natives who controlled the

\footnotetext{
${ }^{1}$ The causality is worth stressing here. While the modern globalization-inequality debate chases the causation from globalization to within-country inequality, the period 1500-1800 was characterized by population pressure on the land which raised land rents and thus the incomes of Europe's rich. Rising inequality increased the demand for imported luxuries, causing a trade boom. It also caused a boom in all well-placed European ports around the Atlantic economy. It seems to me that a recent paper by Acemoglu, Johnson and Robinson (2002) has the causality wrong.
} 
natural resources that were the base of their exports. As a result, the globalization-induced domestic relative price shocks were even bigger and more ubiquitous in Asia and Africa than those in the Atlantic economy (Williamson 2002). To put it another way, commodity price convergence between the European industrial core and the periphery was even more dramatic than it was within the Atlantic economy.

In short, the liberal dismantling of mercantilism and the world-wide transport revolution worked together to produce truly global commodity markets across the nineteenth century. The persistent decline in transport costs world wide allowed competitive winds to blow hard where they had never blown before. True, there was an anti-global policy reaction after 1870 in the European center but it was nowhere near big enough to cause a return to the pre-1820 levels of economic isolation. On the other hand, these globalization events were met with rising levels of protection in Latin America, the United States, and the European periphery, and to very high levels, as Figure 3 documents. However, I postpone until the end of this lecture the question as to whether it was globalization backlash that triggered protection in the periphery or whether it was something else. If history is to offer any lessons for the present, we had better get the causes of backlash straight.

Factor markets also became more integrated world wide. As European investors came to believe in strong growth prospects overseas, global capital markets became steadily more integrated, reaching levels in 1913 that may not have been regained even today (Clemens and Williamson 2001b; Obstfeld and Taylor 2002). International migration soared in response to unrestrictive immigration policies and falling steerage costs (Hatton and Williamson 1998), but not without some backlash: New World immigrant subsidies began to evaporate toward the end of the century, political debate over immigrant restriction became very intense, and, finally, the quotas were imposed. In this case, it is clear that the retreat from open immigration policies to quotas was driven by complaints from the losers at the bottom of the income pyramid, the unskilled native born (Goldin 1994; Timmer and Williamson 1998; Williamson 1998). 


\section{Epoch III Beating an Anti-Global Retreat 1913-1950}

The globalized world started to fall apart after 1913, and it was completely dismantled between the wars. New policy barriers were imposed restricting the ability of poor populations to flee miserable conditions for something better, barriers that exist today, a century later. Thus, the foreign-born share in the United States population fell from a pre-1913 figure of 14.6 percent to an interwar figure of 6.9 percent. Higher tariffs and other non-tariff barriers choked off the gains from trade. Thus, barrier-ridden price gaps between Atlantic economy trading partners doubled, returning those gaps to 1870 levels (Lindert and Williamson 2002a: Table 1). The appearance of new disincentives reduced investment in the diffusion of new technologies around the world, and the share of foreign capital flows in GDP dropped from 3.3 to 1.2 percent (Obstfeld and Taylor 1998: p. 359). In short, the interwar retreat from globalization was carried entirely by anti-global economic policies.

\section{Epoch IV The Second Global Century 1950-2002}

Globalization by any definition resumed after World War II. It has differed from pre-1914 globalization in several ways (Baldwin and Martin 1999). Most important by far, factor migrations are less impressive: the foreign-born are a much smaller share in labor-scarce economies than they were in 1913, and capital exports are a smaller percentage of GDP in the postwar United States (0.5 percent in 1960-73 and 1.2 percent 1989-96: Obstfeld and Taylor 1998, Table 11.1) than they were in prewar Britain (4.6 percent in 1890-1913). On the other hand, trade barriers are probably lower today than they were in 1913. These differences are tied to policy changes in one dominant nation, the United States, which has switched from a protectionist welcoming immigrants to a free trader restricting their entrance.

Ever since Hecksher and Ohlin wrote almost a century ago (Flam and Flanders 1991), their theory has taught that trade can be a substitute for factor migration. While modern theory is much more ambiguous on this point, history is not: in the first global century, before quotas and restrictions, factor 
mobility had a much bigger impact on factor prices, inequality, and poverty than did trade (Taylor and Williamson 1997). Perhaps this explains why the second global century has been much more enthusiastic about commodity trade than about migration. In any case, I start with the more recent globalization experience, the second global century.

\section{Did the Second Global Century Make the World More Unequal?}

\section{International Income Gaps: A Postwar Epochal Turning Point?}

The Bourguignon and Morrisson evidence in Figure 1 documents what looks like a mid-twentieth century turning point in their between-country inequality index, since its rise slows down after 1950 . However, the Bourguinon and Morrisson long-period data base contains only 15 countries. Using postwar purchasing-power-parity data for a much bigger sample of 115, Arne Melchior, Kjetil Telle and Henrik Wiig (2000) actually document a decline in their between-country inequality index in the second half of the twentieth century, and Xavier Sala-i-Matin (2002) shows the same when focusing on poverty. The first three authors document stability in between-country inequality up to the late 1970s, followed by convergence. Four other studies find the same fall in between-country inequality after the early $1960 \mathrm{~s}$ (Schultz 1998; Firebaugh 1999; Boltho and Toniolo 1999; Radetzki and Jonsson 2000). ${ }^{2}$ Among these recent studies, perhaps the most useful in identifying an epochal regime switch is that of Andrea Boltho and Gianni Toniolo (1999), who show a rise in between-country inequality in the 1940s, rough stability over the next three decades, and a significant fall after 1980, significant enough to make their betweencountry inequality index drop well below its 1950 level.

Did the postwar switch from autarky to global integration contribute to this epochal change in the

\footnotetext{
${ }^{2}$ They all use purchasing-power-parity data for which the fall is far clearer. Indeed, it disappears in studies that use income data in US dollars (Melchior, Telle and Wiig 2000: p. 16).
} 
evolution of international gaps in average incomes?

\section{Trade Policy and International Income Gaps: Late Twentieth Century Conventional Wisdom}

Conventional (static) theory argues that trade liberalization should have benefited Third World countries more than it benefitted leading industrial countries. After all, trade liberalization should have a bigger effect on the terms of trade of countries joining the larger integrated world economy than on countries already members. ${ }^{3}$ And the more the change in the terms of trade, the bigger the gain in GDP per capita.

So much for theory. Reality suggests the contrary. After all, the postwar trade that was liberalized the most was in fact intra-OECD trade, not trade between the OECD and the rest. From the very beginning in the 1940s, the General Agreement on Tariffs and Trade explicitly excused low-income countries from the need to dismantle their import barriers and exchange controls. This GATT permission served to lower GDP in low-income countries below what might have been, but the permission was consistent with the anti-global ideology prevailing in previously-colonial Asia and Africa, in Latin America where the great depression hit so hard, and in eastern Europe dominated as it was by statedirected USSR. Thus the succeeding rounds of liberalization over the first two decades or so of GATT brought freer trade and gains from trade mainly to OECD members. However, these facts do not show that late twentieth century globalization favored rich countries. Rather, they show that globalization favored all (industrial) countries who liberalized and penalized those (pre-industrial) who did not.

There is, of course, an abundant literature showing that liberalizing Third World countries gained from freer trade after the OECD leaders set the liberal tone, after the 1960s.

\footnotetext{
${ }^{3}$ For example, when Mexico joined NAFTA in 1994, its economy was only about 6 percent the size of the United States. Furthermore, only about 9 percent of US trade was with Mexico, while about 75 percent of Mexican imports and 84 percent of Mexican exports involved the US (Robertson 2001: p. 1). These shares suggest that Mexico satisfied the "small country assumption" and took North American market prices as given, thus getting the full measure of terms of trade gains by going open.
} 
First, the authors of a large National Bureau of Economic Research project assessed trade and exchange-control regimes in the 1960s and 1970s by making classic partial-equilibrium calculations of deadweight losses (Bhagwati and Krueger 1973-1976). They concluded that the barriers imposed significant costs in all but one case. However, these welfare calculations came from standard models which did not allow protection a chance to lower long-run cost curves as would be true of the traditional infant-industry case, or to foster industrialization and thus growth, as would be true of those modern growth models where industry is the carrier of technological change and capital deepening. Thus, economists have looked for more late twentieth century proof to support the openness-fosters-growth hypothesis.

Second, analysts have contrasted the growth performance of relatively open with relatively closed economies. The World Bank has conducted such studies for 41 Third World countries going back before the first oil shock. The correlation between trade openness and growth is abundantly clear in these studies, as illustrated in Table 1. Yet, such analysis is vulnerable to the criticism that the effect of trade policies alone cannot be isolated since other policies usually change at the same time. Thus, countries that liberalized their trade also liberalized their domestic factor markets, liberalized their domestic commodity markets, and set up better property-rights enforcement. The appearance of these domestic policies may deserve more credit for raising income while the simultaneous appearance of more liberal trade policies may deserve less.

Third, there are country event studies, where the focus is on periods when Third World trade policy regimes change dramatically enough to see their effect on growth. For example, Anne Krueger $(1983,1984)$ looked at trade opening moments in South Korea around 1960, Brazil and Colombia around 1965, and Tunisia around 1970. Growth improved after liberalization in all four cases. More recently, David Dollar and Aart Kraay (2000a) examined the reforms and trade liberalizations of 16 countries in the 1980s and 1990s, finding, once again, the positive correlation between freer trade and faster growth. 
Of course, these reform episodes may have changed more than just global participation, so that an independent trade effect may not have been isolated.

Fourth, macro-econometric analysis has been used in an attempt to resolve the doubts left by simpler historical correlations revealed by the other three kinds of studies. This macro-econometric literature shows that free trade policies have had a positive effect on growth in the late twentieth century, especially with many other relevant influences held constant. The most famous of these is by Jeffrey Sachs and Andrew Warner (1995), but many others have also confirmed the openness-fosters-growth hypothesis for the late twentieth century (e.g. Dollar 1992; Edwards 1993; Dollar and Kraay 2000a).

In spite of this evidence, it must be said that there are still some skeptics who doubt that support for the openness-fosters-growth hypothesis is unambiguous, of which more later.

\section{When the Twentieth Century Leader Went Open: The United States}

The recent American surge in wage and income inequality generated an intense search for its sources. First, there were the globalization sources. These included the rise in unskilled worker immigration rates, due to rising foreign immigrant supplies and to a liberalization of United States immigration policy. Increasing competition from imports that used unskilled labor intensively was added to the globalization impact, a rising competition due to foreign supply improvements (aided by US outsourcing), international transportation improvements, and trade-liberalizing policies. Second, there were sources apparently unrelated to globalization, like a slowdown in the growth of per worker skill supply and biased technological change that cut the demand for unskilled workers relative to skilled workers.

The debate evolved into a 'trade versus technology' contest, although it might have learned far more by greater attention to immigration and skills (or schooling) supply. Some contestants agree with Adrian Wood $(1994,1998)$ that trade was to blame for much of the wage widening. Others contestants 
reject this conclusion, arguing that most or all of the widening was due to a shift in technology that has been strongly biased in favor of skills. Most estimates tend to resemble the guess by Robert Feenstra and Gordon Hanson (1999) that perhaps 15-33 percent of the rising inequality was due to trade competition. Still, everyone seems to agree that going open in late twentieth century was hardly egalitarian for America.

William Cline offers the boldest attempt at an overall quantitative accounting of these potential sources. Cline blames globalization less than do most writers, and concludes that skill-biased technological change is bigger than any globalization effect (Cline 1997: Table 5.1). Cline's interpretation of his own estimates is, however, very different from mine, and perhaps my historical perspective accounts for the difference. The proper question, it seems to me, is left unasked by Cline and other economists in the debate: namely, how did the period 1973-1993 differ from the one that preceded it, 1953-1973? If the other sources added up to pretty much the same impact in the first postwar period, then it would be the change in globalization forces between the two periods that mattered. Thus, it seems to me that Cline's study illustrates how economists throw away information by confining their analysis to the recent widening of wage gaps. When the world economy became increasingly integrated in the two centuries before 1980, technology also had its factor bias, and the mismatch between technological bias and skills growth kept shifting, with inequality implications (Williamson and Lindert 1980; Goldin and Katz 1999, 2000; Lindert 2000). Why ignore this history?

\section{Globalization, Inequality and the OECD}

The United States wasn't the only OECD country to undergo a recent rise in inequality. The trend toward wider wage gaps has also been unmistakable in Britain. Although there wasn't much widening in full-time labor earnings for France or Japan, and none at all for Germany or Italy, income 
measures that take work hours and unemployment into account reveal some widening even in those last four cases. A recent study surveyed the inequality of disposable household income in the OECD since from the mid-1970s (Burniaux et al. 1998). Up to the mid-1980s, the Americans and British were alone in having a clear rise in inequality. From the mid-1980s to the mid-1990s, however, 20 out of 21 OECD countries had a noticeable rise in inequality. Furthermore, the main source of rising income inequality after the mid-1980s was the widening of labor earnings. The fact that labor earnings became more unequal in most OECD countries, when full-time labor earnings did not, suggests that many countries took their inequality in the form of more unemployment and hours reduction, rather than in wage rates.

\section{Globalization, Inequality and the Third World}

The sparse literature on the wage-inequality and trade liberalization connection in developing countries is mixed in its findings and narrow in its focus. It has concentrated on six Latins (Argentina, Chile, Colombia, Costa Rica, Mexico, and Uruguay) and three East Asians (Korea, Singapore, and Taiwan), and the assessment diverges sharply between regions and epochs. Wage gaps seemed to fall when the three Asian tigers liberalized in the 1960s and early 1970s. Yet wage gaps generally widened when the six Latin American countries liberalized after the late 1970s (Wood 1994, 1997, 1998; Robbins 1997; Robbins and Gindling 1999; Hanson and Harrison 1999). Why the difference?

As Adrian Wood (1997) has rightly pointed out, historical context was important, since other things were not equal during these liberalizations. The clearest example where a Latin wage widening appears to refute the egalitarian Stolper-Samuelson prediction was the Mexican liberalization under Salinas in 1985-1990. Yet this pro-global liberalization move coincided with the major entry of China and other Asian exporters into world markets. Thus Mexico faced intense new competition from less skill-intensive manufactures in all export markets. Historical context could also explain why trade liberalization coincided with wage widening in the five other Latin countries, and why it coincided with 
wage narrowing in East Asia in the 1960s and early 1970s. Again, timing matters. Competition from other low-wage countries was far less intense when the Asian tigers pulled down their barriers in the 1960s and early 1970s compared with the late 1970s and early 1980s when the Latin Americans opened up.

But even if these findings were not mixed, they could not have had a very big impact on global inequalities. After all, the literature has focused on nine countries that together had less than 200 million people in 1980, while China by itself had 980 million, India 687 million, Indonesia 148 million, and Russia 139 million. All four of these giants recorded widening income gaps after their economies went global. The widening did not start in China until after 1984, because the initial reforms were rural and agricultural and therefore had an egalitarian effect. When the reforms reached the urban industrial sector, China's income gaps began to widen (Griffin and Zhao 1993, esp. p. 61; Atinc 1997). India's inequality has risen since liberalization started in the early 1990s. Indonesian incomes became increasingly concentrated in the top decile from the 1970s to the 1990s, though this probably owed more to the Suharto regime's ownership of the new oil wealth than to any conventional trade-liberalization effect. Russian inequalities soared after the collapse of the Soviet regime in 1991, and this owed much to the handing over of trading prerogatives and assets to a few oligarchs (Flemming and Micklewright 2000).

\section{Border Effects, Limited Access and the Third World}

Income widening in these four giants dominates global trends in within-country inequality, ${ }^{4}$ but

\footnotetext{
${ }^{4}$ The giants also dominate trends in between-country inequality. Much of the fall in the between-country inequality index offered by Melchior, Telle and Wiig (2000, p. 15) is due to the fact that the populations in Japan and the US are getting relatively fewer and less rich, while those in China and India are getting richer and more populous.
} 
how much was due to liberal trade policy and globalization? Probably very little. Indeed, much of the inequality surge during their liberalization experiments seems linked to the fact that the opening to trade and foreign investment was incomplete. That is, the rise in inequality appears to have been based on the exclusion of much of the population from the benefits of globalization. The question is what accounts for the exclusion? China, where the gains since 1984 have been so heavily concentrated in the coastal cities and provinces (Griffin and Zhao 1993; Atinc 1997), offers a good example. Those that were able to participate in the new, globally-linked economy prospered faster than ever before, while the rest in the hinterland were left behind, ${ }^{5}$ or at least enjoyed less economic success. China's inequality had risen to American levels by 1995 (a gini of .406), but the pronounced surge in inequality from 1984 to 1995 was dominated by the rise in urban-rural and coastal-hinterland gaps, not by widening gaps within any given locale. This pattern suggests that China's inequality -- like that of Russia, Indonesia and other giants -has been raised by differential access to the benefits of the new economy, not by widening gaps among those who participate in it, or among those who do not. But why have the globalization-induced growth shocks favored China's coastal provinces? How much is due to policy, and how much to border effects associated with external trade, effects that have favored the coastal provinces for centuries?

Consider another example. In the aftermath of GATT-related liberalization in 1986 and of NAFTA-related liberalization in 1994, Mexico has undergone rising inequality, not falling inequality as most observers predicted. However, Gordon Hanson (2002) has shown that much of this result can be traced to an uneven regional stimulus and, in particular, to the boom along the US border. Is it only a matter of waiting for these 'border effects' to spread? Apparently, since Raymond Robertson (2001) has shown that the Stolper-Samuelson predictions work just fine for Mexico after 1994, if one allows for a 3 5 year lag.

\footnotetext{
${ }^{5}$ Migration from the hinterland to the cities was pretty much prohibited before the mid-1990s.
} 


\section{Did the First Global Century Make the World More Unequal?}

\section{Global Divergence Without Globalization}

Figure 1 documents the rise of income gaps between nations since 1820. While the evidence may not be as precise, we also know that global income divergence started long before 1820. Indeed, international income gaps almost certainly widened after 1600 or even earlier. Real wages, living standards, health and (especially) output per capita indicators all point to an early modern 'great divergence' which took place in three dimensions -- between European nations, within European nations and between Europe and Asia. Real wages in England and Holland pulled away from the rest of the world in the late seventeenth century (van Zanden 1999; Pomeranz 2000; Allen 2001; Pamuk and Ozmucur 2002). Furthermore, between the sixteenth and the eighteenth centuries the landed and merchant classes in England, Holland, and France pulled far ahead of everyone -- their compatriots, the rest of Europe, and probably any other region on earth. This divergence was even greater in real than in nominal terms, because luxuries became much cheaper relative to necessities (Hoffman et al. 2002; Allen et al. 2002). While we will never have firm estimates of the world income gaps between 1500 and 1820 , what we do have suggest unambiguously that global inequality rose long before the First Industrial Revolution. Thus, industrial revolutions were never a necessary condition for widening world income gaps. It happened with industrial revolutions and it happened without them. ${ }^{6}$

Despite the popular rhetoric about an early modern world system, there was no true globalization move after the 1490s and the voyages of de Gama and Columbus. As I argued previously using Figure 2, intercontinental trade was monopolized, and huge price markups between exporting and importing ports were maintained even in the face of improving transport technology. Furthermore, most of the traded

\footnotetext{
${ }^{6}$ Granted, nineteenth century industrial revolutions greatly contributed to an acceleration in the growing gap between industrial core and pre-industrial periphery (e.g. Pritchett 1997).
} 
commodities were non-competing: that is, they were not produced at home and thus did not displace some competing domestic industry. In addition, these traded consumption goods were luxuries out of reach of the vast majority of each trading country's population. In short, pre-1820 trade had only a trivial impact on the living standards of anyone but the very rich. Finally, and as I pointed out above, the migration of people and capital was only a trickle before the 1820 s. True globalization began only after the 1820 s.

Thus, while global income divergence has been with us for more than four centuries, globalization has been with us for less than two. This conflict raises serious doubts about the premise that rising world integration is responsible for rising world inequality. According to history, globalization has never been a necessary condition for widening world income gaps. It happened with globalization and it happened without it.

\section{When the Nineteenth Century Leader Went Open: Britain}

Britain's nineteenth-century free-trade leadership, especially its famous Corn Law repeal in 1846, offers a good illustration of how the effects of global liberalization depend on the leader, and how the effects of going open can be egalitarian for both the world and for the liberalizing leader. The big gainers from nineteenth century British trade liberalization were British labor -- especially unskilled labor -- and the rest of Europe and its New World offshoots, while the clear losers were British landlords, the world's richest individuals (Williamson 1990). How much the rest of the world gained (and whether British capitalists gained at all) depended on foreign-trade elasticities and induced terms of trade effects. But since these terms of trade effects were probably quite significant for what was then called 'the workshop of the world,' Britain must have distributed considerable gains to the rest of the world as well as to her own workers. Workers -- especially unskilled workers -- gained because Britain was a food- 
importing country ${ }^{7}$ and because labor was used much less intensively in import-competing agriculture than was land (Irwin 1988; Williamson 1990). Whether and how much the periphery gained also must have depended on de-industrialization there, a long run force I explore further below.

History offers two enormously important historical cases where the world leader going open had completely different effects: pro-global liberalization in nineteenth century Britain was unambiguously egalitarian at the national and, in the short run at least, the world level; American liberalization in the late twentieth century was not.

\section{European Followers and the New World}

What about the globalization and inequality connection for the rest of Europe and its New World offshoots? Two kinds of (admittedly imperfect) evidence document distributional trends within countries participating in the global economy. One relies on trends in the ratio of unskilled wages to farm rents per acre, a relative factor price whose movements launched inequality changes in a world where the agricultural sector was big and where land was a critical component of total wealth. ${ }^{8}$ It tells us how the typical unskilled worker near the bottom of the income pyramid did relative to the typical landlord at the top $(\mathrm{w} / \mathrm{r})$. The other piece of inequality evidence relies on trends in the ratio of the unskilled wage to GDP per worker (w/y). These trends tell us whether the typical unskilled worker near the bottom was catching up with or falling behind the income recipient in the middle.

When w/r and w/y trends are plotted for the Atlantic economy against initial labor scarcity between 1870 and World War I (Williamson 1997), they conform to the conventional globalization prediction (Figure 4). Inequality fell and equality rose in land-scarce and labor-abundant Europe either

\footnotetext{
${ }^{7}$ Labor would not have gained much from free trade on the continent since, among other things, agriculture was a far bigger employer, so big that the employment effects (the nominal wage) dominated the consumption effects (the cost of living). See O'Rourke (1997).

${ }^{8}$ Agricultural output and land input shares are certainly smaller today even in the Third World, but to ignore them in inequality debate is a mistake. Yet, economists studying the Third World seem to have an obsession with earnings distributions.
} 
due to trade boom, or to mass emigration, or to both, as incomes of the abundant factor (unskilled labor) rose relative to the scarce factor (land). In addition, those who faced the onslaught of cheap foreign grain after 1870, but chose not to impose high tariffs on grain imports (like Britain, Ireland and Sweden), recorded the biggest loss for landlords and the biggest gain for workers. Those who protected their landlords and farmers against cheap foreign grain (like France, Germany and Spain) generally recorded a smaller decline in land rents relative to unskilled wages. To the extent that globalization was the dominant force, inequality should have fallen in labor-abundant and land-scarce Europe. And fall it did. However, these egalitarian effects were far more modest for the European industrial leaders who, after all, had smaller agricultural sectors. Land was a smaller component of total wealth in the European industrial core where improved returns on industrial capital, whose owners were located near the top of the income distribution, at least partially offset the diminished incomes from land, whose owners tended to occupy the very top of the income distribution.

Globalization had an inegalitarian effect in the land-abundant and labor-scarce New World, and for symmetric reasons. Not surprisingly, Latin America, the United States, Australia, Canada and Russia all raised tariffs to defend themselves against an invasion of European manufactures and the deindustrialization it would have caused (Coatsworth and Williamson 2002; Blattman, Clemens and Williamson 2002). Indeed, the levels of protection in the United States, Canada, Australia, Latin America and the European periphery were huge compared to continental Europe. Figure 5 reports that in the 1880s the US and Latin America had tariffs five to six times higher than western Europe, and the European periphery had levels three times higher! It is absolutely essential to know why tariffs were so much higher in the periphery than in the European core up to the 1930s, but we save this discussion for the end of the lecture.

\section{Terms of Trade Gains in the Periphery before 1913}


Terms of trade movements might signal who gains the most from trade, and a literature at least two centuries old has offered opinions about whose terms of trade should improve most and why (Diakosavvas and Scandizzo 1991; Hadass and Williamson 2002). Classical economists thought the relative price of primary products should rise given an inelastic supply of land and natural resources. This conventional wisdom took a revisionist U-turn in the 1950s when Hans Singer and Raoul Prebisch argued that since 1870 the terms of trade had deteriorated for poor countries in the periphery -- exporting primary products, while they had improved for rich countries in the center - exporting industrial products.

The terms of trade can be influenced by changes in transport costs and changes in policy. It can also be influenced by other events, such as world productivity growth differentials across sectors, demand elasticities, and factor supply responses. Since transport costs declined so dramatically in the first global century (O'Rourke and Williamson 1999; Williamson 2002), this is one likely source that served to raise everybody's terms of trade. Furthermore, and as we have seen, rich countries like Britain took a terms-of-trade hit when they switched to free trade by mid-century, an event that must have raised the terms of trade in the poor, non-industrial periphery even more. But in some parts of the periphery, especially before the 1870 s, other factors were at work that mattered even more, and they greatly reinforced these pro-global forces.

Probably the most powerful nineteenth century globalization shock did not involve transport revolutions at all. It happened in Asia, and it happened in mid century. Under the persuasion of American gun ships, Japan switched from virtual autarky to free trade in 1858. In the fifteen years following 1858 , Japan's foreign trade rose 70 times, from virtually nil to 7 percent of national income (Huber 1971). The prices of exportables soared in home markets, rising towards world market levels. The prices of importables slumped in home markets, falling towards world market levels. One researcher estimates that, as a consequence, Japan's terms of trade rose by a factor of 4.9 over those fifteen years (Yasuba 
1996). Thus, the combination of declining transport costs world wide and a dramatic switch from autarky to free trade unleashed a powerful terms of trade gain for Japan.

Other Asian nations followed this liberal path, most forced to do so by colonial dominance or gunboat diplomacy. Thus, China signed a treaty in 1842 opening her ports to trade and adopting a 5 percent ad valorem tariff limit. Siam adopted a 3 percent tariff limit in 1855 . Korea emerged from its autarkic Hermit Kingdom a little later (with the Treaty of Kangwha in 1876), undergoing market integration with Japan long before colonial status became formalized in 1910. India went the way of British free trade in 1846, and Indonesia mimicked Dutch liberalism. In short, and whether they liked it or not, Asia underwent tremendous improvements in their terms of trade by this policy switch, and it was reinforced by declining transport costs world wide.

For the years after 1870, there is better evidence documenting terms of trade movements the world around, country by country (Williamson 2002: Hadass and Williamson 2002). Contrary to the assertions which Prebisch and Singer made a half-century ago, not only did the terms of trade improve for a good share of the poor periphery ${ }^{9}$ up to World War I, but they improved a lot more than they did in Europe. Over the four decades prior to World War I, the terms of trade rose by only 2 percent in the European center, by almost 10 percent in East Asia, and by more than 21 percent in the Southern Cone, Egypt and India combined.

Why am I able to report such different historical findings than did Prebisch and Singer, or than did W. Arthur Lewis a little later? One reason is that I have only reported the terms of trade performance during the first global century (up to 1913), not during the anti-global interlude that followed. Another reason is that the peripheral terms of trade reported here are those which prevailed in each home market

\footnotetext{
${ }^{9}$ In two of the studies cited (Williamson 2002; Hadass and Williamson 2002), the periphery sample is limited to nine: Argentina, Burma, Egypt, India, Japan, Korea, Taiwan, Thailand and Uruguay. This sample from the periphery is augmented by twelve more in the third study: Brazil, Ceylon, Chile, China, Columbia, Cuba, Greece, Indonesia, Mexico, the Philippines, Peru, and Turkey (Blattman, Clemens and Williamson 2002).
} 
(e.g. Alexandria, Bangkok or Montevideo), not the inverse of those prevailing in London or New York. In a world where transport costs plunged steeply, everybody could have found their terms of trade improving, but some primary producers in the periphery actually enjoyed the biggest pre-war improvements. If other members of the periphery did not enjoy the same big gains, it was not the fault of globalization induced by transport revolutions and liberal policy. Rather, the fault lay with the characteristics of those primary products

This pre-1913 terms of trade experience seems to imply that globalization favored some parts of the poor periphery even more than it did the rich center, and to that extent it must have been a force for more equal world incomes. That inference is probably false. Over the short run, positive and quasipermanent terms of trade shocks of foreign origin will always raise a nation's purchasing power, and the issue is only how much. Over the long run a positive terms-of-trade shock in primary-product-producing countries should reinforce comparative advantage, pull resources into the export sector, thus causing deindustrialization. To the extent that industrialization is the prime carrier of capital-deepening and technological change, then economists like Singer were right to caution that positive external price shocks for primary producers might actually lower growth rates in the long run. Of course, small-scale, rural cottage industry isn't the same as large-scale, urban factories, so industry may not have been quite the carrier of growth in the 1870 periphery that it might be in the Third World today. In any case, while nobody has yet tried to decompose the short run and long run components of quasi-permanent terms of trade shocks like these, there has been a recent effort to explore the possibility that positive terms of trade shocks had a negative effect around the periphery (Hadass and Williamson 2002). Adding terms of trade variables to a now-standard empirical growth model and estimating that model for a nineteen-country sample between 1870 and 1940, confirms that an improving terms of trade augmented long-run growth in the center. However, the same terms of trade improvement was growth-reducing in the periphery. It appears that the short-run gain from an improving terms of trade was overwhelmed by a long-run loss 
attributed to de-industrialization in the periphery; in contrast, the short-run gain was reinforced by a longrun gain attributed to industrialization in the center.

These results imply that globalization-induced (positive) terms of trade shocks before World War I were serving to augment the growing gap between rich and poor nations. Did the same happen after 1950 when Prebisch, Singer and other critics of conventional policy were so vocal? Maybe. Is the same true today, fifty years later? Probably not. After all, manufactures have been a rapidly rising share of developing country output and exports over the past three decades. The share of manufactures in the total commodity exports in developing countries rose spectacularly from around 30 percent in 1970 to more than 75 percent in 2002 (Hertel, Hoekman and Martin 2002: Figure 2). To put it the other way around, agricultural and mineral primary product exports as a share in total exports fell from 70 to 25 percent over the past thirty years in the Third World.

Enough of the Third World is now sufficiently labor-abundant and natural-resource-scarce so that their comparative advantage lies with (simple, labor-intensive) manufactures, implying that the growth of trade has helped it industrialize. The classic image of Third World specialization in primary products has almost evaporated.

\section{Rising Inequality in the Primary Product Exporting Periphery}

There were powerful global forces at work before 1913 and the Third World was very much a part of it. There was commodity price convergence within and between Europe, the newly-settled nonLatin countries, Latin America and Asia, and the price convergence was bigger in the periphery than it was in the core. The convergence was driven by a transport revolution that was more dramatic in the Asian periphery where, in addition, it was not offset by tariff intervention. It also appears that relative factor prices converged world-wide at the same time that average living standards and income per capita 
diverged sharply between center and periphery. ${ }^{10}$ The relative factor price convergence was manifested by falling wage-rental ratios in land-abundant and labor-scarce countries, and rising wage-rental ratios in land-scarce and labor-abundant countries. The convergence took place everywhere around the globe.

These events set in motion powerful inequality forces in land and resource abundant areas, especially around the pre-industrial periphery, as in Southeast Asia and the Southern Cone. Quite the opposite forces were at work in land and resource scarce areas, like East Asia.

These distributional events in the periphery were ubiquitous and powerful (Williamson 2002). They must have had important implications for political developments which probably persisted well in to the late twentieth century, just as W. Arthur Lewis' research agenda always implied.

\section{North-North and South-South Mass Migrations, with Segmentation in Between}

North-North migrations between Europe and the New World involved the movement of something like 60 million individuals. We know a great deal about the determinants and impact of these mass migrations. South-South migration within the periphery was probably even greater, but we know very little about its impact on sending regions (like China and India), on receiving regions (like East Africa, Manchuria and Southeast Asia), or on the incomes of the 60 million or so who moved. As Lewis (1978) pointed out long ago, the South-North migrations were only a trickle: like today, poor migrants from the periphery were kept out of the high-wage center by restrictive policy, by the high cost of the move, and by their lack of education. World labor markets were segmented then just as they are now.

Real wages and living standards converged among the currently-industrialized countries between 1850 and World War I (Figure 6). ${ }^{11}$ The convergence was driven primarily by the erosion of the gap

\footnotetext{
${ }^{10}$ These facts deserve stress. While there was income per capita and living standards divergence between center and periphery in the first global century, there was powerful convergence in relative factor prices. One wonders whether the same has been true in the second global century, and, if so, why economists haven't noticed it.

${ }^{11}$ Figure 6 plots convergence in the Atlantic economy for sample sizes of 13, 15 and 17. The largest sample includes: Argentina, Australia, Brazil, Canada, the United States; Belgium, Denmark, France, Germany, Great
} 
between the New World and Europe. In addition, many poor European countries were catching up with the industrial leaders. How much of this convergence in the Atlantic economy was due to North-North mass migration?

The labor force impact of these migrations on each member of the Atlantic economy in 1910 varied greatly (Taylor and Williamson 1997). Among receiving countries, Argentina's labor force was augmented most by immigration (86 percent), Brazil's the least (4 percent), with the United States in between (24 percent). Among sending countries, Ireland's labor force was diminished most by emigration (45 percent), France the least (1 percent), with Britain in between (11 percent). At the same time, the economic gaps between rich and poor countries diminished: real wage dispersion in the Atlantic economy declined between 1870 and 1910 by 28 percent, GDP per capita dispersion declined by 18 percent and GDP per worker dispersion declined by 29 percent (Taylor and Williamson 1997; Hatton and Williamson 1998). What contribution did the mass migration make to that convergence?

Migration affects equilibrium output, wages and living standards by influencing aggregate labor supply, and these effects have also been estimated. In the absence of the mass migrations, wages and labor productivity would have been a lot higher in the New World and a lot lower in Europe. The biggest impact, of course, was on those countries that experienced the biggest migrations. Emigration is estimated to have raised Irish wages by 32 percent, Italian by 28 percent and Norwegian by 10 percent. Immigration is estimated to have lowered Argentine wages by 22 percent, Australian by 15 percent, Canadian by 16 percent and American by 8 percent.

This partial equilibrium assessment of migration's impact is higher than a general equilibrium assessment would be since it ignores trade and output mix adjustments, as well as domestic and global capital market responses, all of which would have muted the impact of migration. In any case, the

Britain, Ireland, Italy, the Netherlands, Norway, Portugal, Spain, Sweden (Williamson 1996; O'Rourke and Williamson 1999). 
assessment certainly lends strong support to the hypothesis that mass migration made an important contribution to late nineteenth century convergence in the 'North.' In the absence of the mass migrations, real wage dispersion between members of the Atlantic economy would have increased by 7 percent, rather than decrease by 28 percent, as it did in fact. In the absence of mass migration, wage gaps between Europe and the New World would have risen from 108 to 128 percent when in fact they declined to 85 percent. These results have been used to conclude that migration was responsible for all of the real wage convergence before World War I and about two-thirds of the GDP per worker convergence.

There was an additional and even more powerful effect of North-North mass migrations on "northern" income distribution. So far I have only discussed the effect of migration on convergence in per worker averages between countries; I have not discussed the impact of migration on income distribution within the Atlantic economy as a whole. To do so, I would need to add on the large income gains accruing to the 60 million (poor) Europeans who moved overseas. Typically, these migrants came from countries whose average real wages and average GDP per worker were perhaps only half of those in the receiving countries. These migrant gains were a very important part of the net equalizing effect on "northern" incomes of the mass migrations.

North-North mass migrations had a strong leveling influence in the North up to 1913. They made it possible for poor migrants to improve the living standards for themselves and their children. It also lowered the scarcity of resident New World labor which competed with the immigrants, while it raised the scarcity of the poor European labor that stayed home (whose incomes were augmented still further by emigrant remittances). South-South and North-North migrations were about the same size. Until new research tells us otherwise, ${ }^{12}$ I think it is safe to assume that South-South migrations put powerful downward pressure on real wages and labor productivity in Ceylon, Burma, Malaysia, Thailand, East

\footnotetext{
12 Timothy J. Hatton and I are embarking on that South-South migration project, covering the years from about 1850 to the present.
} 
Africa, Manchuria and other labor scarce regions that received so many Indian and Chinese immigrants.

Since the sending labor surplus areas were so huge, it seems less likely that the emigrations served to raise labor scarcity there by much.

\section{The Unimportance of Global Capital Markets}

Using ceteris paribus assumptions, I have just concluded that mass migration accounted for all of the real wage convergence observed in the Atlantic economy during the first global century. But ceteris was not paribus since there were other powerful forces at work, capital accumulation responses being one of them. Capital accumulation was rapid in the New World, so much so that the rate of capital deepening was faster in the United States than in any of its European competitors, and the same was probably true of other rich New World countries. Thus, the mass migrations may have been at least partially offset by capital accumulation, and a large part of that accumulation was being financed by international capital flows which reached magnitudes unsurpassed since. One study has made exactly this kind of adjustment (Taylor and Williamson 1997) by implementing the zero-migration counterfactual in a model where the labor supply shocks generate capital flow responses that maintain a constant rate of return on capital (e.g. perfect global capital market integration). ${ }^{13}$ The assumed capital-chasing-labor offsets are certainly large in this experiment, but mass migration still explains about 70 percent of the convergence, leaving only about 30 percent to other forces.

Capital market responses were simply not big enough to deflate significantly the powerful income-leveling effects of mass migration within what we now call the OECD. Indeed, while it is true that global capital markets were at least as well integrated prior to World War I as they are today (Obstfeld and Taylor 1998, 2002), capital flows were mainly an anti-convergence force. This statement

\footnotetext{
${ }^{13}$ In a recent paper, Davis and Weinstein (2002) do the same for the US today, agreeing that all factor inflows, capital and labor, should be looked at together.
} 
is, of course, inconsistent with simple two-factor-theory prediction that capital should flow from rich to poor countries. It never did. As Robert Lucas (1990) made famous, Table 2 shows that British capital inflows and GDP per capita were positively, not negatively, correlated just before World War I and that the same was true for all private capital inflows in the 1990s (Clemens and Williamson 2001b; see also Obstfeld and Taylor 2002). The wealth bias that Lucas and others have noticed was just as powerful a century ago, and it is explained by the fact that capital chased after abundant natural resources, youthful populations, and human-capital abundance. It did not chase after cheap labor.

International capital flows were an anti-convergence force. They drifted towards rich, not poor, countries; they raised wages and labor productivity in the labor-scarce and resource-abundant New World, not the labor-abundant Third World. And what was true of the first global century has also been true of the second. But this does not imply that the Third World has been losing capital by export. ${ }^{14}$ Rather, it implies that there has always been a churning of capital among richer countries outside of Asia and Africa.

\section{Trade Policy and International Income Gaps: Why the Big Regime Switch?}

If free trade has been good for economic growth since World War II, ${ }^{15}$ why was it bad for growth before? About thirty years ago, Paul Bairoch (1972) argued that protectionist countries grew faster in the nineteenth century, not slower as every economist has found for the late twentieth century. Bairoch's sample was mainly from the European industrial core, it looked at pre-1914 experience only, and it invoked unconditional analysis, controlling for no other factors. Like some modern studies (see Table 1), Bairoch simply compared growth rates of major European countries in protectionist and free trade

\footnotetext{
${ }^{14}$ Apparently, Africa has suffered significant capital flight in recent times. Indeed, as of 1990, Africans placed a huge 39 percent of their wealth portfolios outside the region, a year when the figure was 3 percent for South Asia, 6 percent for East Asia and 10 percent for Latin America (Collier and Gunning 1999: p. 92). This is hardly surprising given that the region has suffered negative terms of trade shocks, civil war and confiscation.

15 Or at least not harmful for growth: pace Rodriguez and Rodrik (2001).
} 
episodes. More recently, Kevin O'Rourke (2000) got the Bairoch finding again, this time using macroeconometric conditional analysis on a ten country sample drawn from the pre-1914 Atlantic economy (Australia, Canada, Denmark, France, Germany, Italy, Norway, Sweden, UK, US). In short, these two scholars were not able to find any evidence before World War I supporting the openness-fosters-growth hypothesis. ${ }^{16}$

These pioneering historical studies suggest that there was a fundamental tariff-growth regime switch somewhere between the start of World War I and the end of World War II: before the switch, protection fostered growth; after the switch, protection hindered growth. Michael Clemens and Jeffrey Williamson (2001a) think the best explanation for the tariff-growth paradox is the fact that: During the interwar, and led by the industrial powers, tariff barriers facing the average exporting countries rose to very high levels; and since World War II, again led by the industrial powers, tariff barriers facing the average exporting country fell to their lowest levels in a century and a half. A well-developed theoretical literature on strategic trade policy ${ }^{17}$ predicts that nations have an incentive to inflate their own terms of trade by tariffs, but thereby to lower global welfare - a classic prisoner's dilemma. Inasmuch as favorable terms of trade translate into better growth performance and tariffs are non-prohibitive, we might expect the association between own tariffs and growth to depend at least in part on the external tariff environment faced by the country in question. A fter accounting for changes in world policy environment, Clemens and Williamson show that there is no incompatibility between the positive tariffgrowth correlation before 1914 and the negative tariff-growth correlation since 1970.

It has not always been true that open countries finish first, and it need not be true in the future either. There is growing evidence suggesting that the benefits of openness are neither inherent nor

\footnotetext{
16 There are two additional studies worth mentioning here. Capie (1983) found support for the Bairoch hypothesis using event analysis with a pre-1914 European sample of four (Germany, Italy, the UK and Russia). Vamvakidis (2002) couldn't find any interwar evidence supporting the openness-fosters-growth hypothesis either, although it was (once again) based on a small, mostly OECD sample.

${ }^{17}$ Exemplified by Dixit (1987) and recently surveyed in Bagwell and Staiger (2000).
} 
irreversible but rather depend upon the state of the world. When considering the move to openness, heads of state are facing a game, not an isolated decision. The low-level equilibrium of mutually high tariffs is only as far away as some big world event that persuades influential leader-countries to switch to anti-global policies. Feedback ensures that the rest must follow in order to survive. Thus, today's low-tariff equilibrium was only as far away as OECD coordination in the early postwar years, and the creation of trans-national public institutions whose express purpose was to impede a return to interwar anti-global autarky.

But what sparks such shifts from one equilibrium to another? Why did it happen in the 1920s and 1950s? Could it happen again?

\section{Trade Policy and International Income Gaps: What About the Pre-1940 Periphery?}

Were Latin America, Eastern Europe and the rest of the periphery part of this paradox, or was it only an attribute of the industrial core? While the recent work cited above has shown that protection fostered growth in the industrial core before World War II, it also shows that it did not do so in most of the periphery (Clemens and Williamson 2001a; Coatsworth and Williamson 2002). Table 3 reports this result, where the model estimated is of the convergence variety, but it is conditioned only by the country's own tariff rate and regional dummies. The tariff rate and GDP per capita level are both measured at year $t$, while the subsequent GDP per capita growth rate is measured over the half decade following. ${ }^{18}$ The two world wars are ignored.

The tariff-growth paradox is stunningly clear in Table 3. In columns (1) and (3), the estimated coefficient on log of the tariff rate is 0.14 for $1875-1908$ and 0.36 for $1924-1934$. Thus, and in contrast with late twentieth century evidence, tariffs were associated with fast growth before 1939. But was this

\footnotetext{
${ }^{18}$ Thus, the last pre-World War II observation is 1934, which relates to growth between 1934 and 1939, and the last pre-World War I observation is 1908, which relates to the growth between 1908 and 1913.
} 
true for all regions, or was there instead an asymmetry between industrial economies in the core and primary-producers in the periphery? Presumably, the protecting country has to have a big domestic market, and has to be ready for industrialization, accumulation, and human capital deepening if the long run tariff-induced dynamic effects are to offset the short run gains from trade given up. Table 3 tests for asymmetry in columns (2) and (4), and the asymmetry hypothesis wins. That is, protection was associated with faster growth in the European core and their English-speaking offshoots (the coefficient on own tariff $1875-1908$ is 0.56 and highly significant), but it was not associated with fast growth in the European or Latin American periphery, nor was it associated with fast growth in interwar Asia (when tariffs rose even in the colonies: see Figure 5). Indeed, before World War I protection in Latin America was associated significantly and powerfully with slow growth.

The moral of the story is while policy makers in Latin America, eastern Europe and the Mediterranean may, after the 1860 s, have been very aware of the pro-protectionist infant-industry argument ${ }^{19}$ offered for a newly-integrated (zollverein) Germany by Frederich List or for a newlyindependent (economically-federated) United States by Alexander Hamilton, there is absolutely no evidence which would have supported those arguments in the periphery. We must look elsewhere for plausible explanations for the exceptionally high tariffs in Latin America and the European periphery during the first global century.

\section{Lessons of History 1: Will There Be South-North Mass Migration in Our Future?}

\footnotetext{
19 Late nineteenth century Latin American policy makers were certainly were so aware (Bulmer-Thomas 1994: 140). However, it is important to stress "late" since the use of protection specifically and consciously to foster industry does not occur until the 1870s or 1890s: e.g. Argentina with the 1876 tariff; Mexico by the early 1890s; Chile with its new tariff in 1897; Brazil in the 1890s; and Colombia in early 1900s (influenced by Mexican experience). So, the qualitative evidence suggests that domestic industry protection becomes a motivation for Latin American tariffs only in the late nineteenth century.
} 
It might be useful to repeat what we have learned about the mass European emigration: almost all of the observed income convergence in the Atlantic economy, or what we are now calling the North, was due to this North-North mass migration, and that same movement also generated more equal incomes in the labor-abundant sending regions. It is important to remember this fact when dealing today with the second global century.

Although the migrations were immense during the age of mass North-North and South-South migration prior to World War I, there was hardly any South-North migration to speak of. Thus, while the mass migration to labor scarce parts of the North played a big role in erasing poverty in the labor surplus parts of the North, it did not help much to erase poverty in the South. The same is true today. Will this world labor market segmentation break down in the near future? It all depends on policy. Certainly demographic and educational forces are contributing to the breakdown of world labor market segmentation along South-North lines. As young adult shares shrink in the elderly OECD, and while they swell in the young Third World going through demographic transitions, perhaps the pressure will become too great to resist the move to a more liberal OECD immigration policy, especially in Europe and Japan. The educational revolution in the Third World (Easterlin 1981: Schultz 1987) has helped augment this pressure, as potential emigrants from poor countries are better equipped to gain jobs in the OECD (Clark, Hatton and Williamson 2002; Hatton and Williamson 2002).

The two underlying fundamentals that drove European emigration in the late nineteenth century were the size of real wage gaps between sending and receiving regions -- a gap that gave migrants the incentive to move, and demographic booms in the low-wage sending regions -- a force that served to augment the supply of potential movers (Hatton and Williamson 1998). These two fundamentals are even more prominent in Africa today, and recent work suggests that Africans seem to be just as responsive to them as were Europeans a century ago (Hatton and Williamson 2001, 2002). Although this is no longer an age of unrestricted intercontinental migration, new estimates of net migration for the countries of sub- 
Saharan Africa suggest that exactly the same forces are at work driving African cross-border migration today. Rapid growth in the cohort of young potential migrants, population pressure on the resource base, and poor economic performance are the main forces driving African emigration. In Europe a century ago, more modest demographic increases were accompanied by strong catching-up economic growth in lowwage emigrant regions. Furthermore, the sending regions of Europe eventually underwent a slowdown in demographic growth serving to choke off some of the mass migration. Yet, migrations were still mass. Africa today offers a contrast: economic growth has faltered, its economies have fallen further behind the leaders, and there will be a demographic speed up in the near future. The pressure on African emigration is likely to intensify, including a growing demand for entrance into high-wage labor markets of the developed world. Indeed, if European doors were swung open, there is an excellent chance that by 2025 Africa would record far greater mass migrations than did nineteenth century Europe. The demographic unknown in this equation is, of course, African success in controlling the spread of the HIV/AIDS. If it is controlled early, then these emigration predictions are more likely to prevail.

This analysis for African emigation has been recently extended to US immigration by source from 1971 to 1998 (Clark, Hatton and Williamson 2002; Hatton and Williamson 2002). Here again, the economic and demographic fundamentals that determine immigration rates across source countries are estimated -- income, education, demographic composition and inequality. The analysis also allows for persistence in these patterns as they arise from the impact of the existing immigrant stock B big foreignborn stocks implying strong friends and neighbors=effects. M ost of these Third W orld fundamentals will be serving to increase the demand for high-wage jobs in the OECD.

How will the OECD respond to this challenge? If it opens its doors wider, the mass migrations would almost certainly have the same influence on leveling world incomes and eradicating poverty that it did in the first global century. It would help erode between-country North-South income gaps, and it would improve the lives of the millions of poor Asians and Africans allowed to make the 
move. And it would help eradicate poverty among those who would not move, making their labor more scarce at home and augmenting their incomes by remittances, forces that were powerful in pre-quota Europe a century ago.

Inequality would rise in the OECD, of course, just as it did in the immigrant-absorbing New World a century ago. Perhaps not as much, since the unskilled with whom the immigrants compete are a much smaller share of the OECD labor force today, but inequality would rise just the same. Are we ready to pay that price? Perhaps not. Indeed, we have seen how rising inequality created an anti-global backlash a century ago, a backlash that included a retreat into immigrant restriction that still characterizes the high-wage OECD today.

\section{Lessons of History 2: Absolute or Relative Income? Nominal or Real Income?}

The debate over the impact of globalization on world inequality almost always measures performance in relative terms. The questions posed are: Have international income gaps between poor and rich countries widened with globalization? Has inequality within countries widened with globalization? Something is very wrong with these questions and the measures they imply. Here are better questions: If gaps between rich and poor countries have widened, and if globalization is the cause, is it because poor countries have not gained from going global, or is it because they have actually lost? If the gaps between rich and poor within countries have widened, and if globalization is the cause, is it because poor citizens have not gained by their country going global, or is it because they have actually lost?

To the extent that policy is driven by the absolute losses to vocal citizens and/or vocal nations, rather than relative losses, it is all the more amazing that so many contemporary economists insist on using relative inequality measures. Economic historians know better. I offer two examples. 
Example 1: During the great British political debates over a move to free trade in the decades before the 1846 Repeal of the Corn Laws, predicted impact was always assessed both by reference to nominal incomes on the employment side and to consumption goods prices on the expenditure side. Indeed, free traders called the high duties on agricultural imports 'bread taxes' (Williamson 1990), and thought that the relative price of this wage good (grain) was central to working class living standards. And they were absolutely right! Since grain -- and its derivative bread -- made up such an enormous share of working class budgets, the falling relative price of this importable made a fundamental contribution to the rise in real wages and the living standards of the poor.

Example 2: During the great rise in European inequality between 1500 and 1800, when Malthusian forces dominated the closed European economy (O'Rourke and Williamson 2002a, 2002c), staple food and fuels became more expensive, while luxury goods, like imported exotics and domestic servants, became cheaper (Hoffman et al. 2002). These relative price changes served to augment rising nominal inequality and, indeed, to reduce living standards of the working poor. What happened in the nineteenth century when Europe went open? The price of imported food fell, contributing to the absolute real wage gains associated with the industrial revolution, and to an absolute decline in land rents. What had been a pre-globalization inegalitarian price effect was converted into a post-globalization egalitarian price effect. And since the poor devote such a large share of their budget to food, the poorest gained the most.

Economic historians cannot take all the credit for asking the right questions, since one can also find a few rare examples in the huge literature on the current globalization-inequality connection. David Dollar and Aart Kraay (2000b) report from late twentieth century country cases and cross-country analysis that globalization leads to poverty reduction in poor countries, and that (Dollar and Kraay 
$2000 \mathrm{~b}$ ) trade openness beneifts the poor as much as it benefits all others. ${ }^{20}$ Of course, it may not be the poor who vote, and thus the impact of going open on their economic performance may unimportant to policy formation in poor countries and thus to the survival of global liberialism there.

The two historical examples from the first global century suggest an agenda for the second global century. If going global has had a real impact on participating economies over the past three decades, then we should see its impact on relative commodity prices in home markets: the price of importables should have fallen relative to the price of exportables and perhaps even relative to the price of nontradables. What do the rich and poor consume in these countries? What happened to the cost of their consumption market baskets when their country went open? Did the price movements on the expenditure side serve to reinforce or offset income movements on the employment side? The answers to these questions are very hard to find in the literature on the second global century. True, some time ago William Cline (1980) asked whether world commodity price shocks had much to do with within country nominal income inequality, concluding "not much," while, as I pointed out above, Robertson (2001) recently asked the same question of Mexico since NAFTA, concluding a "great deal." ${ }^{21}$ But do globalinduced relative commodity changes induce uneven real income changes on the expenditure side to the extent that the poor consume a very different market basket than the rich? They certainly did for Vietnam in the 1990s. According to Eric Edmonds and Nina Pavcnik (2002), during the liberal period between 1993 and 1998 the price of rice rose by 29 percent relative to the Vietnamese CPI, and this relative price change must have had important inegalitarian effects on the expenditure side since the budget of the poor in that country is so dominated by rice.

\footnotetext{
${ }^{20}$ A more recent study by Sala-i-Matin (2002) is more descriptive, asking what happened from 1970 to 1998 , assigning no blame or applause to causes. He shows that while poverty rates have fallen since 1970, within-country inequality has increased. See also Chen and Ravallion (2001).

${ }^{21}$ To quote Robertson (2001: p. 3): "When Mexico joined the GATT, it opened its borders to trade with an arguably labor-abundant world, which may explain why it protected less-skill-intensive industries. Joining NAFTA, however, deepened integration with skill-abundant ... US and Canada. The relative price of skill-intensive goods reversed its rise. As suggested by the Stolper-Samuelson theorem, relative wages also reversed their trend."
} 
It seems to me that economists should be searching for contemporary cases where the expenditure budgets of the rich and poor are very different, and where the rich consume in large proportions skill and capital intensive importables plus the services of the poor, and where the poor consume in large proportions land-intensive food and housing. They should also search for countries that have a recent history of switching from anti-global to pro-global policies. The best places to find both conditions satisfied are, of course, poor countries in Asia and Africa.

\section{Lessons of History 3: Accommodating the Losers with Safety Nets and Suffrage}

Any force that creates more within-country inequality is automatically blunted today -- at least in the OECD, a point that is sometimes overlooked in the inequality debate. That is, any rise in the inequality of households' net disposable post-fisc income will always be less than the rise in gross prefisc income inequality. Any damage to the earnings of low-skilled workers is partially offset by their lower tax payments and higher transfer receipts, like unemployment compensation or family assistance. Broadening the income concept therefore serves to shrink any apparent impact of globalization on the inequality of living standards. And by muting their losses, such safety nets also, presumably, mute political backlash.

So far, so good. But does globalization destroy these automatic stabilizers by undermining taxes and social transfer programs? In a world where businesses and skilled personnel can flee taxes they don't like, there is the well-known danger that governments might compete for internationally mobile factors by cutting tax rates and thus social spending. As Jonas Agell $(1999,2000)$ and Dani Rodrik $(1997,1998)$ have stressed, however, the relationship between a country's vulnerability to international markets and the size of its tax-based social programs is positive, not negative as a "race to the bottom" would imply. Thus, countries with greater global market vulnerability have higher taxes, more social spending, and 
broader safety nets. Furthermore, 'vulnerability' to global market changes is in part an endogenous policy choice: there is a trade-off between going open and investing in safety nets. In any case, while there may be other reasons for the positive correlation between openness and social programs, there is no apparent tendency for globalization to undermine the safety nets.

While these stabilizers certainly prevail in the OECD today, one supposes they were not common during the first global century when such safety nets were not yet in place. One also supposes that there was no trade-off between going open and investing in safety nets at that time in what we now call the OECD. If one was inclined to make those suppositions, one would be very wrong. Europe was globalized by 1913 , and the increased market vulnerability created greater wage and employment instability. In a two recent papers, Michael Huberman by himself (2002) and with Wayne Lewchuk (2001) show that authorities responded to workers' complaints by establishing labor market regulations and social insurance programs, and by giving them the vote. Empirical analysis of seventeen European countries shows that the legislation gave workers reason to support free trade. Thus, globalization was compatible with government intervention before 1913 just as it has been since 1950. And, to repeat, the first global century was also one during which the vote was extended increasingly to the previously disenfranchised (Acemoglu and Robinson 2000; Huberman and Lewchuk 2001). It also appears that the two were related!

The interesting question is how long it will take poor nations today to put the same modern safety nets in place and to empower all citizens in the debate over global policy choices.

\section{Lessons of History 4: Why Do Countries Protect?}

What better place to end this lecture than to ask: Why do countries protect? I am aware that the recent decade or so has generated a flourishing theoretical literature on endogenous tariffs. That literature 
is primarily motivated by recent OECD, and mainly US, experience, thus ignoring the enormous variance over time and across regions with very different endowments, institutions and histories.

Look again at Figure 5, where the enormous variance in levels of protection are documented for both the first global century and for the interwar years. Three big facts are revealed by Figure 5. First, tariffs in the independent periphery (Latin America, the non-Latin European offshoots and the European periphery) were vastly higher than they were in the European core. Second, globalization backlash in the first global century was much stronger in the periphery than in the European core (the rise in average tariff rates was much bigger up to World War I). Third, what made the interwar years so autarkic was not a move towards protection in the periphery -- since tariffs in Latin America, the European periphery and the non-Latin offshoots were just about as high in the 1930s as they were before World War I. ${ }^{22}$ What made the interwar years so autarkic was the rise of protection in the European core and the United States.

Economists need to confront these facts and to offer explanations for them. When one does so for Latin America from 1820 to 1950, one finds that the motivations for protection were very complex and changed over time (Coatsworth and Williamson 2002). Those exceptionally high Latin American tariffs were driven up by government revenue needs, strategic tariff reactions to trading partner policy (e. g. very high tariffs in the United States), Stolper-Samuelson lobbying forces, and protection of the local manufacturing industry. Before we can be confident about what causes globalization backlash today, we need to know what caused it in the past. Over the century $1820-1913,{ }^{23}$ only a (perhaps small) part of the anti-global policy in Latin America was driven by development goals, by de-industrialization fears, or by the complaints of the losers. Furthermore, these determinants changed over time: revenue goals diminshed in importance as Latin America became better integrated with global capital markets, as pax

\footnotetext{
${ }^{22}$ Figure 5 measures 'protection' by average tariff levels only, thus ignoring non-tariff barriers. NBTs were on the rise in the interwar, so the indicator in Figure 5 understates the anti-global regime switch.

${ }^{23}$ Chris Blattman, Michael Clemens and I (2002) expand the historical analysis from Latin America to the rest of the world between 1870 and 1937.
} 
americana latina diminished the need for and thus the financial burden of standing armies, and as these young countries developed less-distorting internal tax revenue sources. Economists need to make the same kind of assessment for the second global century if we are to understand the sources of globalization backlash better. 


\section{References}

Acemoglu, Daron and James Robinson. 2000. "Why Did the West Extend the Franchise? Democracy, Inequality, and Growth in Historical Perspective." Quarterly Journal of Economics 461 (November): 1167-1199.

Acemoglu, Daron, Simon Johnson and James Robinson. 2002. "The Rise of Europe: Atlantic Trade, Institutional Change and Economic Growth." Paper presented to the Economic History Workshop, Harvard University (April 5).

Agell, Jonas. 1999. "On the Benfits from Rigid Labour Markets: Norms, Market Failures and Social Insurance." Economic Journal 108 (February): F143-F164.

Agell, Jonas. 2000. "On the Determinants of Labour Market Institutions: Rent Sharing vs. Social Insurance." CESifo Working Paper 384. University of Munich.

Allen, Robert C. 2001. "The Great Divergence: Wages and Prices from the Middle Ages to the First World War." Explorations in Economic History. 38 (October): 411-47.

Allen, Robert C. et al. 2002. "Preliminary Global Price Comparisons, 1500-1870." Paper presented to the XIII Congress of the International Economic History Association, Buenos Aires (July 22-26).

Atinc, Tamar M. 1997. Sharing Rising Incomes: Disparities in China. Washington: The World Bank. Bagwell, Kyle and Robert W. Staiger. 2000. “GATT-Think.” NBER Working Paper 8005. National Bureau of Economic Research, Cambridge, Mass.: NBER.

Baier, Scott J. and Jeffrey H. Bergstrand. 2001. "The Growth of World Trade: Tariffs, Transport Costs, and Income Similarity.” Journal of International Economics 53 (February): 1-27.

Bairoch, Paul. 1972. "Free Trade and European Economic Development in the Nineteenth Century." European Economic Review 3 (November): 211-45.

Baldwin, Richard and Philippe Martin. 1999. “Two Waves of Globalization: Superficial Similarities, 
Fundamental Differences.” NBER Working Paper 6904. National Bureau of Economic Research, Cambridge, Mass. (January).

Berry, Albert, Francois Bourguignon, and Christian Morrisson. 1991. "Global Economic Inequality and Its Trends since 1950.” In L. Osberg, ed., Economic Inequality and Poverty: International Perspectives. Armonk, N.Y.: Sharpe.

Bhagwati, Jagdish and Anne O. Krueger, eds. 1973-1976. Foreign Trade Regimes and Economic Development, multiple volumes with varying authorship. New York: Columbia University Press for the NBER.

Blattman, Chris, Michael A. Clemens and Jeffrey G. Williamson. 2002. "Who Protected and Why? Tariffs the World Around 1870-1937." Paper presented to the conference on The Political Economy of Globalization. Dublin (August 29-31).

Boltho, Andrea and Gianni Toniolo. 1999. “The Assessment: The Twentieth Century -- Achievements, Failures, Lessons." Oxford Review of Economic Policy 15 (4): 1-17.

Bourguignon, François and Christian Morrisson. 2000. "The Size Distribution of Income among World Citizens: 1820-1990.” Unpublished paper. Washington, D. C.: World Bank.

Bulmer-Thomas, Victor (1994). The Economic History of Latin America Since Independence. Cambridge: Cambridge University Press.

Burniaux, Jean-Marc et al. 1998. "Income Distribution and Poverty in Selected OECD Countries." OECD Economics Department Working Paper 189. Paris (March).

Capie, Forrest. 1983. "Tariff Protection and Economic Performance in the Nineteenth Century." In J. Black and L. A. Winters (eds.), Policy and Performance in International Trade. London: Macmillan.

Chen, Shaohua and Martin Ravallion. 2001. "How Did the World's Poorest Fare in the 1990s?" Review of Income and Wealth 47 (September): 283-300. 
Clark, Ximena, Timothy J. Hatton and Jeffrey G. Williamson. 2002. "Where Do US Immigrants Come From, and Why?" NBER Working Paper 8998. National Bureau of Economic Research, Cambridge, Mass. (June).

Clemens, Michael A. and Jeffrey G. Williamson. 2001a. “A Tariff-Growth Paradox? Protection's Impact the World Around 1875-1997.” NBER Working Paper 8459. National Bureau of Economic Research, Cambridge, Mass. (September).

Clemens, Michael A. and Jeffrey G. Williamson. 2001b. "Wealth Bias in the First Global Capital Market Boom, 1870-1913." Unpublished manuscript. (July).

Cline, William R. 1980. "Commodity Prices and the World Distribution of Income." Journal of Policy Modeling 2 (1): 1-17.

Cline, William R. 1997. Trade and Income Distribution. Washington: Institute for International Economics.

Coatsworth, John H. and Jeffrey G. Williamson. 2002. "The Roots of Latin American Protectionism: Looking Before the Great Depression." NBER Working Paper 8999. National Bureau of Economic Research, Cambridge, Mass. (June).

Collier, Paul and Jan W. Gunning. 1999. "Explaining African Economic Performance.” Journal of Economic Literature 37 (March): 64-111.

Davis, Donald and David Weinstein. 2002. "Technological Superiority and the Losses from Migration." Columbia University Department of Economics Discussion Paper 0102-60. Columbia University (May).

Diakosavvas, Dimitris and Pasquale L. Scandizzo. 1991. “Trends in the Terms of Trade of Primary Commodities, 1900-1982: The Controversy and Its Origin.” Economic Development and Cultural Change 39 (January): 231-64.

Dixit, Avinash. 1987. "Strategic Aspects of Trade Policy." In Truman F. Bewley (ed.), Advances in Economic Theory: Fifth World Congress. New York: Cambridge University Press. 
Dollar, David. 1992. “Outward-Oriented Developing Economies Really Do Grow More Rapidly: Evidence from 95 LDCs, 1976-1985.” Economic Development and Cultural Change 40 (April): $523-44$.

Dollar, David and Aart Kraay. 2000a. "Trade, Growth, and Poverty.” Unpublished paper. Washington, D. C.: World Bank (October).

Dollar, David and Aart Kraay. 2000b. "Growth Is Good for the Poor.” Unpublished paper. Washington, D. C.: World Bank (March).

Easterlin, Richard A. 1981. "Why Isn't the Whole World Developed?” Journal of Economic History 41 (March): 1-19.

Edmonds, Eric and Nina Pavcnik. 2002. "Does Globalization Increase Child Labor? Evidence from Vietnam.” NBER Working Paper 8760. National Bureau of Economic Research, Cambridge, Mass. (February).

Edwards, Sebastian. 1993. "Openness, Trade Liberalization, and Growth in Developing Countries." Journal of Economic Literature 31 (September): 1358-94.

Feenstra, Robert C. and Gordon H. Hanson. 1999. "The Impact of Outsourcing and High-Technology Capital on Wages: Estimates for the United States, 1979-1990.” Quarterly Journal of Economics 114 (August): 907-40.

Firebaugh, G. 1999. "Empirics of World Income Inequality.” American Journal of Sociology 104 (6): $1597-630$.

Flam, Henry and M. June Flanders. 1991. Heckscher-Ohlin Trade Theory. Cambridge, Mass.: MIT Press. Flemming, John S. and John Micklewright. 2000. "Income Distribution, Economic Systems, and Transition." In A. Atkinson and F. Bourguignon, eds., Handbook of Income Distribution, volume 1. Amsterdam: Elsevier Science.

Goldin, Claudia. 1994. "The Political Economy of Immigration Restriction in the United States, 1890 to 1921." In C. Goldin and G. D. Libecap, eds. The Regulated Economy: A Historical Approach to 
Political Economy. Chicago: University of Chicago Press.

Goldin, Claudia and Lawrence F. Katz. 1999. "The Returns to Skill in the United States across the $20^{\text {th }}$ Century.” NBER Working Paper 7126. National Bureau of Economic Research, Cambridge, Mass. (May).

Goldin, Claudia, and Lawrence F. Katz. 2000. "Decreasing (and Then Increasing) Inequality in America:

A Tale of Two Half Centuries.” In F. Welch, ed. Increasing Income Inequality in America. Chicago: University of Chicago Press.

Griffin, Keith and Zhao Renwei, eds. 1993. The Distribution of Income in China. New York: St. Martin's Press.

Hadass, Yael S. and Jeffrey G. Williamson. 2002. "Terms of Trade Shocks and Economic Performance 1870-1940: Prebisch and Singer Revisited.” Economic Development and Cultural Change (forthcoming).

Hanson, Gordon. 2002. "Globalization and Wages in Mexico." Paper presented to the IDB Conference on Prospects for Integration in the Americas. Harvard University, Cambridge, Mass. (May 31 - June 1)

Hanson, Gordon and Ann Harrison. 1999. "Trade Liberalization and Wage Inequality in Mexico.” Industrial and Labor Relations Review 52 (January): 271-88.

Hatton, Timothy J. and Jeffrey G. Williamson. 1998. The Age of Mass Migration. Oxford: Oxford University Press.

Hatton, Timothy J. and Jeffrey G. Williamson. 2001. "Demographic and Economic Pressure on African Emigration.” NBER Working Paper 8124. National Bureau of Economic Research, Cambridge, Mass. (March).

Hatton, Timothy J. and Jeffrey G. Williamson. 2002. "What Fundamentals Drive World Migration?" Paper to be presented at the WIDER Conference on Migration, Helsinki (September 27-28).

Hertel, Thomas, Bernard M. Hoekman and Will Martin. 2002. "Developing Countries and a New Round 
of WTO Negotiations.” World Bank Research Observer 17 (Spring): 113-40.

Hirst, Paul Q. and Grahame Thompson. 1996. Globalization in Question: The International Economy and the Possibilities of Governance. Cambridge: Polity Press.

Hoffman, Philip T., David S. Jacks, Patricia A. Levin and Peter H. Lindert. 2002. "Real Inequality in Europe since 1500.” Journal of Economic History 62 (June): 322-55.

Huber, J. Richard 1971. “Effects on Prices of Japan's Entry into World Commerce after 1858.” Journal of Political Economy 79 (May/June): 614-28.

Huberman, Michael. 2002. "International Labor Standards and Market Integration Before 1913: A Race to the Top?" Paper presented to the conference on the Political Economy of Globalization, Dublin (August 29-31).

Huberman, Michael and Wayne Lewchuk. 2001. "The Labor Compact, Openness and Small and Large States Before 1914." Unpublished paper. University of Montreal (August).

Irwin, Douglas A. 1988. "Welfare Effects of British Free Trade: Debate and Evidence from the 1840s." Journal of Political Economy 96 (December): 1142-64.

Krueger, Anne O. 1983. “The Effects of Trade Strategies on Growth.” Finance and Development 20 (June): 6-8.

Krueger, Anne O. 1984. "Trade Policies in Developing Countries.” In R. Jones and P. Kenan, eds., Handbook of International Economics, volume 1. Amsterdam: North-Holland.

Lewis, W. Arthur. 1978. The Evolution of the International Economic Order. Princeton, N.J.: Princeton University Press.

Lindert, Peter H. 2000. “Three Centuries of Inequality in Britain and America.” In A. B. Atkinson and F. Bourguignon, eds., Handbook of Income Distribution, volume 1. Amsterdam: Elsevier Science. Lindert, Peter H. and Jeffrey G. Williamson. 2002a. "Does Globalization Make the World More Unequal?” In M. Bordo, A. M. Taylor and J. G. Williamson (eds.), Globalization in Historical Perspective. Chicago: University of Chicago Press. 
Lindert, Peter H. and Jeffrey G. Williamson. 2002b. "Globalisation et inegalitite: une longue histoire," Revue d'Economie du Developpement (forthcoming).

Lucas, Robert. 1990. “Why Doesn't Capital Flow from Rich to Poor Countries?” American Economic Review 80 (May): 92-6.

Maddison, Angus. 1995. Monitoring the World Economy, 1820-1992. Paris: OECD.

Melchior, Arne, Kjetil Telle and Henrik Wiig. 2000. “Globalisation and Inequality: World Income Distribution and Living Standards, 1960-1998." Studies on Foreign Policy Issues Report 6B: 2000. Royal Norwegian Ministry of Foreign Affairs, Oslo (October).

Obstfeld, Maurice, and Alan M. Taylor. 1998. "The Great Depression as a Watershed: International Capital Mobility over the Long Run.” In M. D. Bordo, C. Goldin and E. N. White, eds., The Defining Moment: The Great Depression and the American Economy in the Twentieth Century. Chicago: University of Chicago Press.

Obstfeld, Maurice, and Alan M. Taylor. 2002. "Globalization and Capital Markets." In M. D. Bordo, A. M. Taylor and J. G. Williamson, eds. Globalization in Historical Perspective. Chicago: University of Chicago Press.

O'Rourke, Kevin H. 1997. "The European Grain Invasion, 1870-1913." Journal of Economic History. 57 (December): 775-801.

O'Rourke, Kevin H. 2000. "Tariffs and Growth in the Late 19th Century." Economic Journal 110 (April): 456-83.

O’Rourke, Kevin H. and Jeffrey G. Williamson. 1999. Globalization and History. Cambridge, Mass.: MIT Press.

O’Rourke, Kevin H. and Jeffrey G. Williamson. 2002a. “After Columbus: Explaining Europe's Overseas Trade Boom, 1500-1800.” Journal of Economic History 62 (June 2002): 417-56.

O’Rourke, Kevin H. and Jeffrey G. Williamson. 2002b. “When Did Globalization Begin?” European Review of Economic History 6, Part 1 (April 2002): 23-50. 
O'Rourke, Kevin H. and Jeffrey G. Williamson. 2002c. "From Malthus to Ohlin: Trade, Growth and Distribution Since 1500." NBER Working Paper 8955. National Bureau of Economic Research, Cambridge, Mass. (May).

Pamuk, Sevket and Suleyman Ozmucur. 2002. "Real Wages and Standards of Living in the Ottoman Empire, 1489-1914." Journal of Economic History 62 (June): 293-321.

Pomeranz, Kenneth. 2000. The Great Divergence: China, Europe, and the Making of the Modern World Economy. Princeton: Princeton University Press.

Pritchett, Lant. 1997. “Divergence, Big Time.” Journal of Economic Perspectives 11 (Summer): 3-18.

Radetzki, M. and B. Jonsson. 2000. “The $20^{\text {th }}$ Century -- the Century of Increasing Income Gaps. But How Reliable Are the Numbers?" Ekonomisk Debatt 1: 43-58.

Robbins, Donald J. 1997. “Trade and Wages in Colombia.” Estudios de Economia 24 (June): 47-83.

Robbins, Donald J. and Tim H. Gindling. 1999. "Trade Liberalization and the Relative Wages for MoreSkilled Workers in Costa Rica.” Review of Development Economics 3 (June): 140-54.

Robertson, Raymond. 2001. "Relative Prices and Wage Inequality: Evidence from Mexico." Unpublished paper. Macalester College (October).

Rodriguez, Francisco and Dani Rodrik. 2001. “Trade Policy and Economic Growth: A Skeptic's Guide to the Cross-National Evidence.” In B. S. Bernake and K. Rogoff (eds.), NBER Macroeconomics Annual 2000, volume 15. Cambridge, Mass.: MIT Press.

Rodrik, Dani. 1997. Has Globalization Gone Too Far? Washington, D.C.: Institute for International Economics.

Rodrik, Dani. 1998. "Why Do More Open Economies Have Bigger Governments?" Journal of Political Economy 106 (October): 997-1033.

Sachs, Jeffrey D. and Andrew Warner. 1995. "Economic Reform and the Process of Global Integration." Brookings Papers on Economic Activity, I. Washington, D.C.: Brookings Institution.

Sala-i-Matin, Xavier. 2002. "The Disturbing 'Rise' of Global Income Inquality." NBER Working Paper 
8904. National Bureau of Economic Research, Cambridge, Mass. (April).

Schultz, T. Paul. 1987. "School Expenditures and Enrollments, 1960-1980: The Effects of Income, Prices, and Population Growth." In D. G. Johnson and R. D. Lee (eds.), Population Growth and Economic Development: Issues and Evidence. Madison, Wisc.: University of Wisconsin Press.

Schultz, T. Paul. 1998. "Inequality in the Distribution of Personal Income in the World: How Is It Changing and Why?" Journal of Population Economics 11 (August): 307-44.

Taylor, Alan M. and Jeffrey G. Williamson. 1997. "Convergence in the Age of Mass Migration." European Review of Economic History 1 (April): 27-63.

Timmer, Ashley and Jeffrey G. Williamson. 1998. "Immigration Policy Prior to the 1930s: Labor Markets, Policy Interactions, and Globalization Backlash.” Population and Development Review 24 (December): 739-71.

Vamvakidis, Athanasios.2002. "How Robust Is the Growth-Openness Connection? Historical Evidence." Journal of Economic Growth 7: 57-80.

van Zanden, Jan Luiten. 1999. "Wages and the Standard of Living in Europe, 1500-1800.” European Review of Economic History 3 (August): 175-98.

Williamson, Jeffrey G. 1990. “The Impact of the Corn Laws Just Prior to Repeal.” Explorations in Economic History 27 (April): 123-56.

Williamson, Jeffrey G. 1996. "Globalization, Convergence, and History.” Journal of Economic History 56 (June): 277-306.

Williamson, Jeffrey G. 1997. "Globalization and Inequality: Past and Present.” World Bank Research Observer 12 (August): 117-35.

Williamson, Jeffrey G. 1998. "Globalization, Labor Markets and Policy Backlash in the Past.” Journal of Economic Perspectives 12 (Fall): 51-72.

Williamson, Jeffrey G. 2002. "Land, Labor, and Globalization in the Third World 1870-1940.” Journal of Economic History 62 (March): 55-85. 
Williamson, Jeffrey G. and Peter H. Lindert. 1980. American Inequality: A Macroeconomic History. New York: Academic Press.

Wood, Adrian. 1994. North-South Trade, Employment and Inequality. Oxford: Clarendon Press.

Wood, Adrian. 1997. “Openness and Wage Inequality in Developing Countries: The Latin American Challenge to East Asian Conventional Wisdom.” World Bank Economic Review 11 (January): $33-57$.

Wood, Adrian. 1998. "Globalisation and the Rise in Labour Market Inequalities.” Economic Journal 108 (September): 1463-82.

Yasuba, Yasukichi. 1996. "Did Japan Ever Suffer from a Shortage of Natural Resources Before World War II?” Journal of Economic History 56 (September): 543-60. 
Table 1

Trade-Policy Orientation and Growth Rates in the Third World, 1963-1992

\begin{tabular}{|c|c|c|c|}
\hline \multirow[b]{2}{*}{ Trade policy orientation } & \multicolumn{3}{|c|}{$\begin{array}{l}\text { Average annual rates growth of GDP per capita } \\
\text { (in percent) }\end{array}$} \\
\hline & $1963-1973$ & $1973-1985$ & 1980-1992 \\
\hline Strongly open to trade & 6.9 & 5.9 & 6.4 \\
\hline Moderately open & 4.9 & 1.6 & 2.3 \\
\hline Moderately anti-trade & 4.0 & 1.7 & -0.2 \\
\hline Strongly anti-trade & 1.6 & -0.1 & -0.4 \\
\hline
\end{tabular}

Sources and notes: Lindert and Williamson (2002a), Table 3 based on the World Bank data. In all periods the three strongly open economies were Hong Kong, South Korea, and Singapore. The identities of the strongly anti-trade countries changed over time. In 1963-1973, they were Argentina, Bangladesh, Burundi, Chile, Dominican Republic, Ethiopia, Ghana, India, Pakistan, Peru, Sri Lanka, Sudan, Tanzania, Turkey, Uruguay, and Zambia. For the two overlapping later periods, the strongly anti-trade countries were the previous sixteen, plus Bolivia, Madagascar, and Nigeria, minus Chile, Pakistan, Sri Lanka, Turkey, and Uruguay. 


\section{Table 2}

\section{Wealth Bias During the T wo G lobal Centuries}

\section{Time period}

Dependent variable

GDP, 1990 US\$

Constant

Estimator

$\mathrm{N}$

$\mathrm{R}^{2}$
1907-1913

A nnual average gross British capital received (flow, in 1990 US\$)

\section{2-1998}

A nnual average change in stock of private capital liabilities

(flow, in 1990 US\$)

0.00467

$(8.68) * * *$

[0.624]

[0.534]

10,700

$(2.43)^{* *}$

[0.965]

$-11,100,000$

$(-1.06)$

97,900

$(2.20)^{* *}$

[0.410]

$-44,700,000$

$(-0.11)$

OLS

155

0.463

t-statistics are in parentheses.

Elasticities (at average regressor values) are in bold square brackets.

*** Significant at the $1 \%$ level. ** Significant at the $5 \%$ level.

Source: Clemens and Williamson (2001b), Table 2. 


\section{Table 3}

\section{Tariff Impact on GDP per capita Growth by Region}

Dependent Variable: $\quad$ 5-Year Overlapping Average Growth Rate

(1)

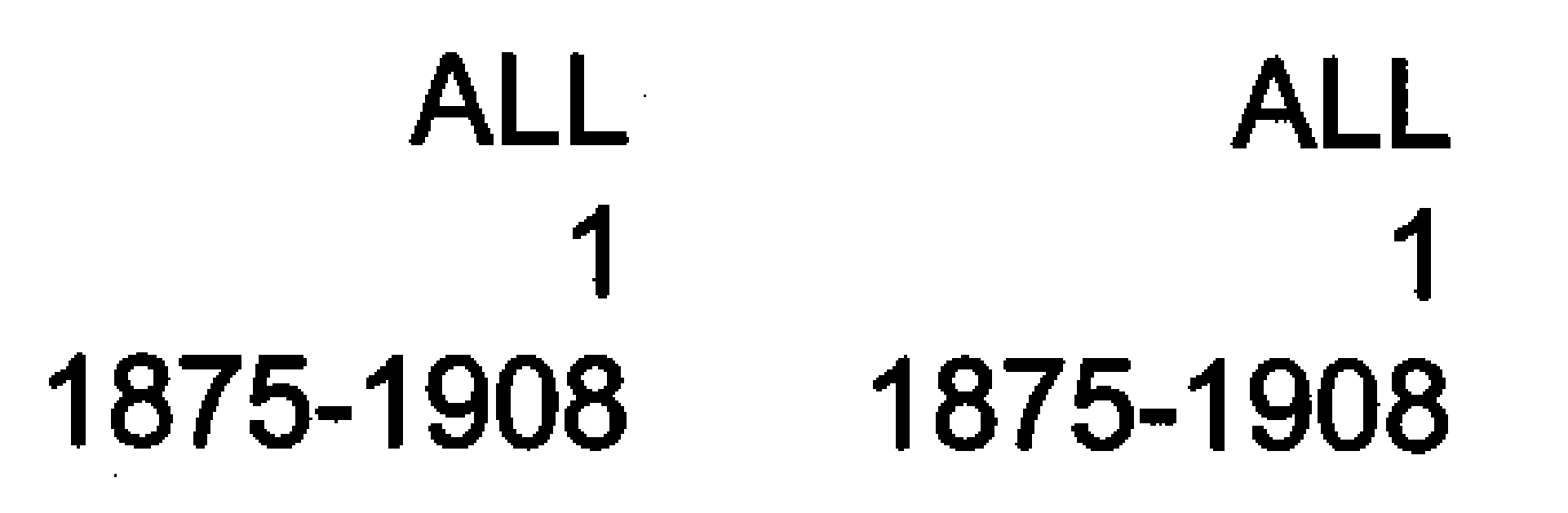

(2)
Included Countries

Years per Period

Time Interval
(3)

(4)

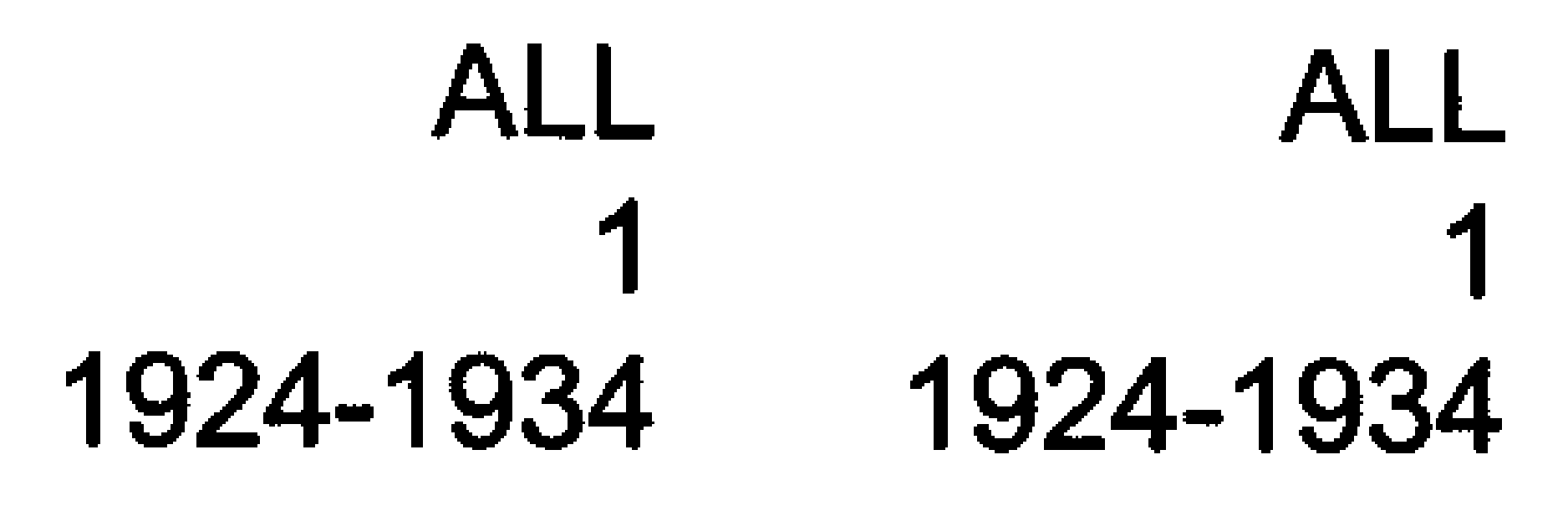

In GDP/capita

0.15

0.10

$-0.73$

0.75

$-1.77$

$-0.89$

1.14

0.56

0.36

1.27

1.65

1.64

3.35

2.83

(European Periphery

$-0.72$

$-2.45$

dummy) x (In tariff rate)

$-3.32$

$-3.18$

(Latin America

$-0.97$

0.58

$-3.15$

0.49

(Asia dummy) $x$

$-0.19$

$-1.47$

(In tariff rate)

$-0.84$

$-2.02$

Euro Periph dummy

$-0.21$

1.58

$-0.04$

6.15

$-1.24$

2.77

$-0.08$

3.10

Latin America dummy

0.19

3.01

$-0.73$

$-3.31$

0.94

3.13

$-1.31$

$-0.96$

Asia dummy

$-0.26$

0.30

$-1.17$

2.39

$-1.09$

0.55

$-1.52$

1.24

Constant

$-0.12$

$-0.11$

$-0.76$

5.92

3.99

$-0.68$

1.55

1.05

Country Dummies?

Time Dummies?

No

No

No

No

No

No

No

No

N

R-squared

1,190

1,190

372

372

Adj. R-squared

0.0357

0.0498

0.0227

0.0605

0.0317

0.0433

0.0094

0.0398 


\section{Figure 1. Global Inequality of Individual Incomes, $1820-1992$}

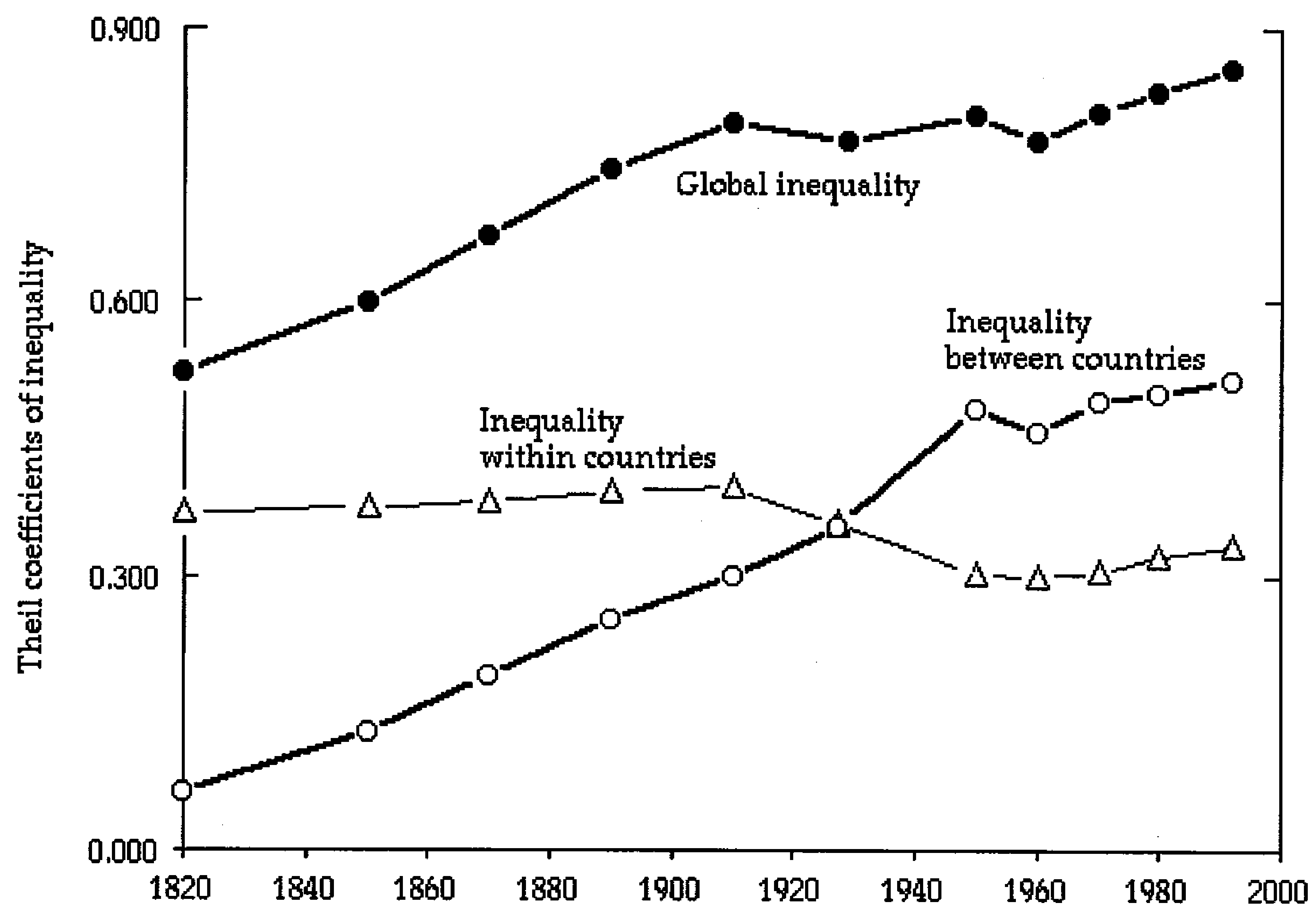

Source: Bourguignon and Morrisson(2001). The "countries" here consist of 15 single countries with abundant data and large populations plus 18 other country groups. The 18 groups were aggregates of geographical neighbors having similar levels of GDP per capita, as estimated by Maddison (1995). 


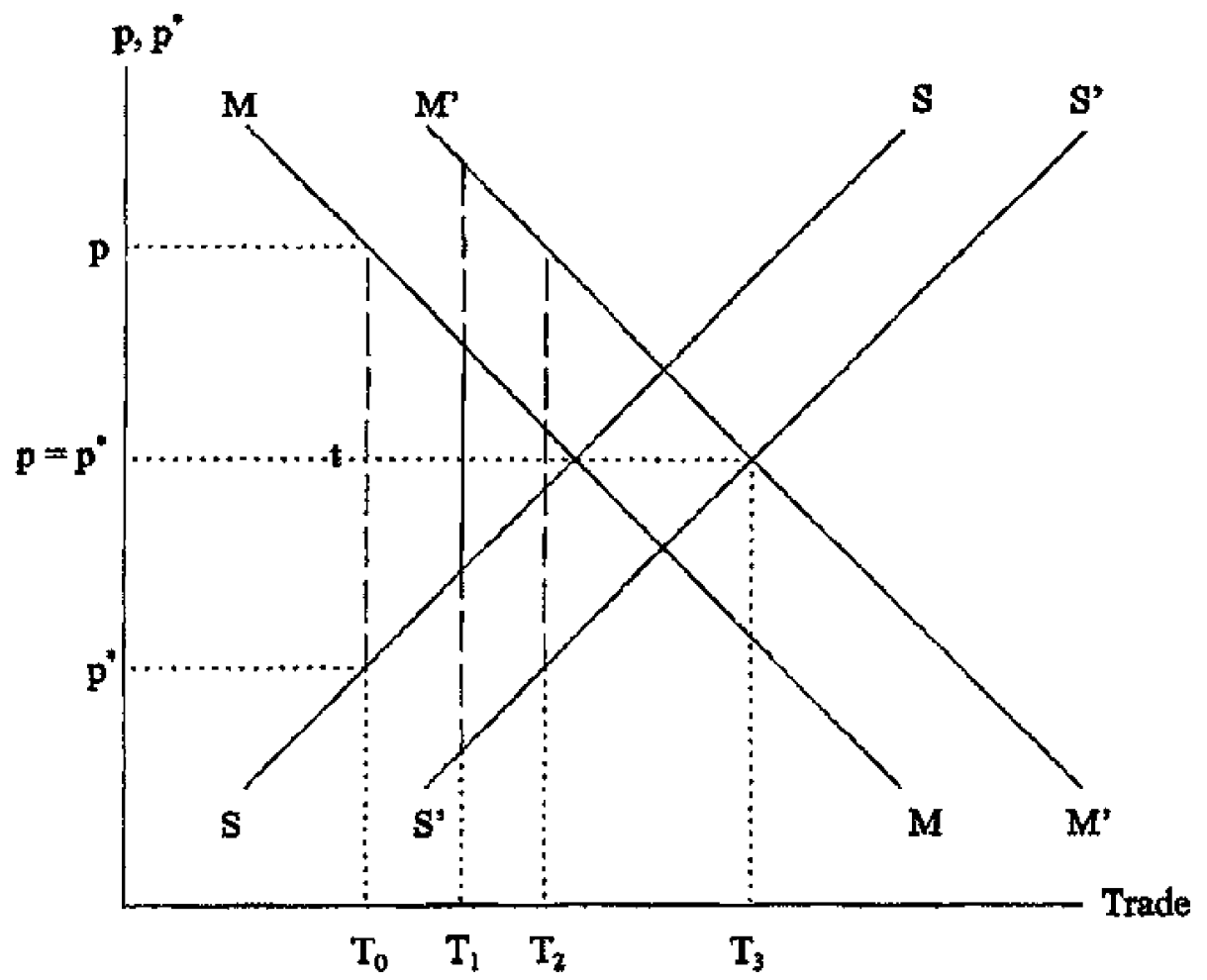

Figure 2

Explaining the European Trade Boom 1500-1800 (Source: O'Rourke and Williamson, 2002a, Figure 3) 


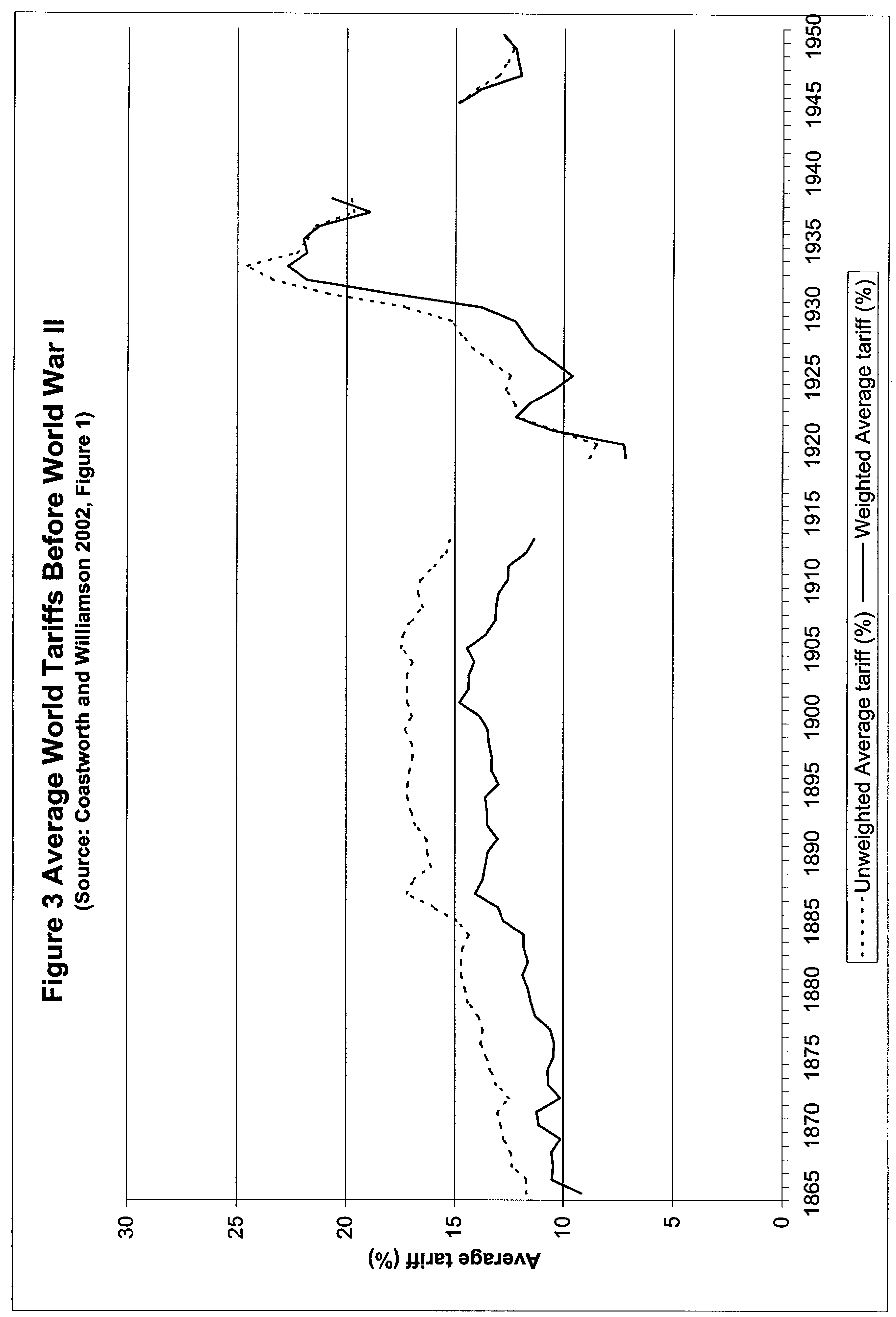




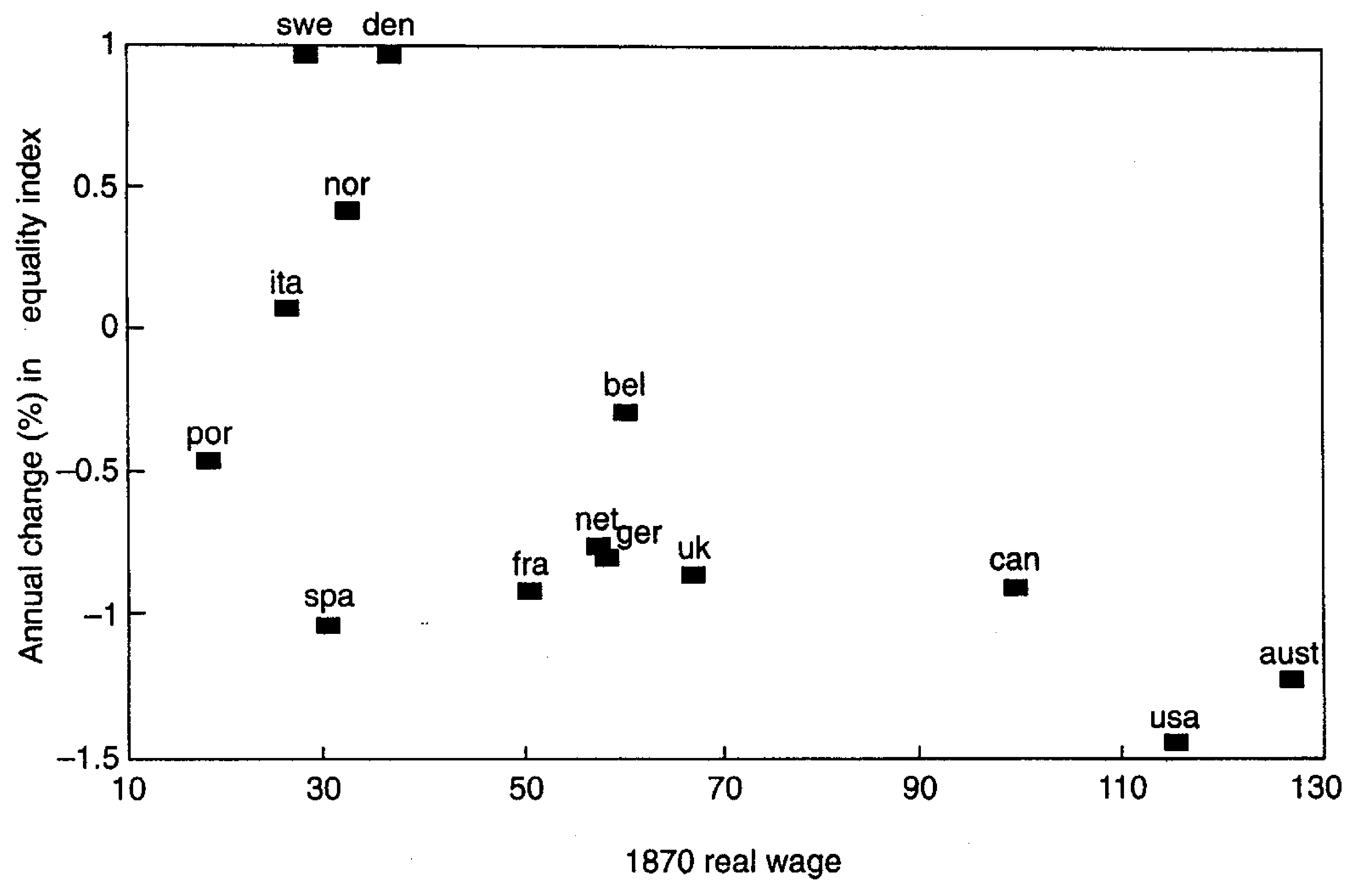

Figure 4

Initial Real Wage versus Subsequent Inequality Trends 1870-1913

(Source: O'Rourke and Williamson, 1999, Figure 9.2) 


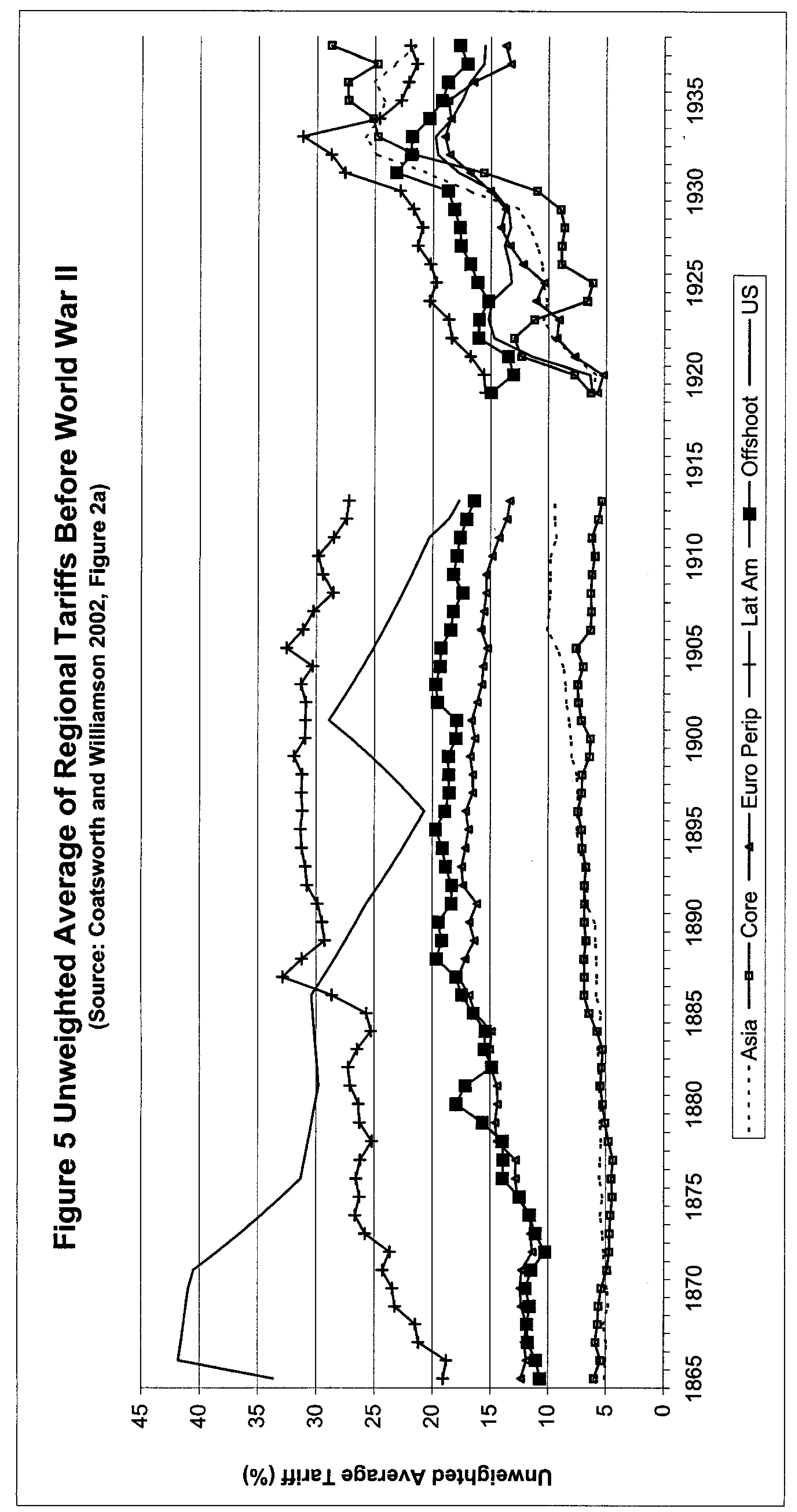




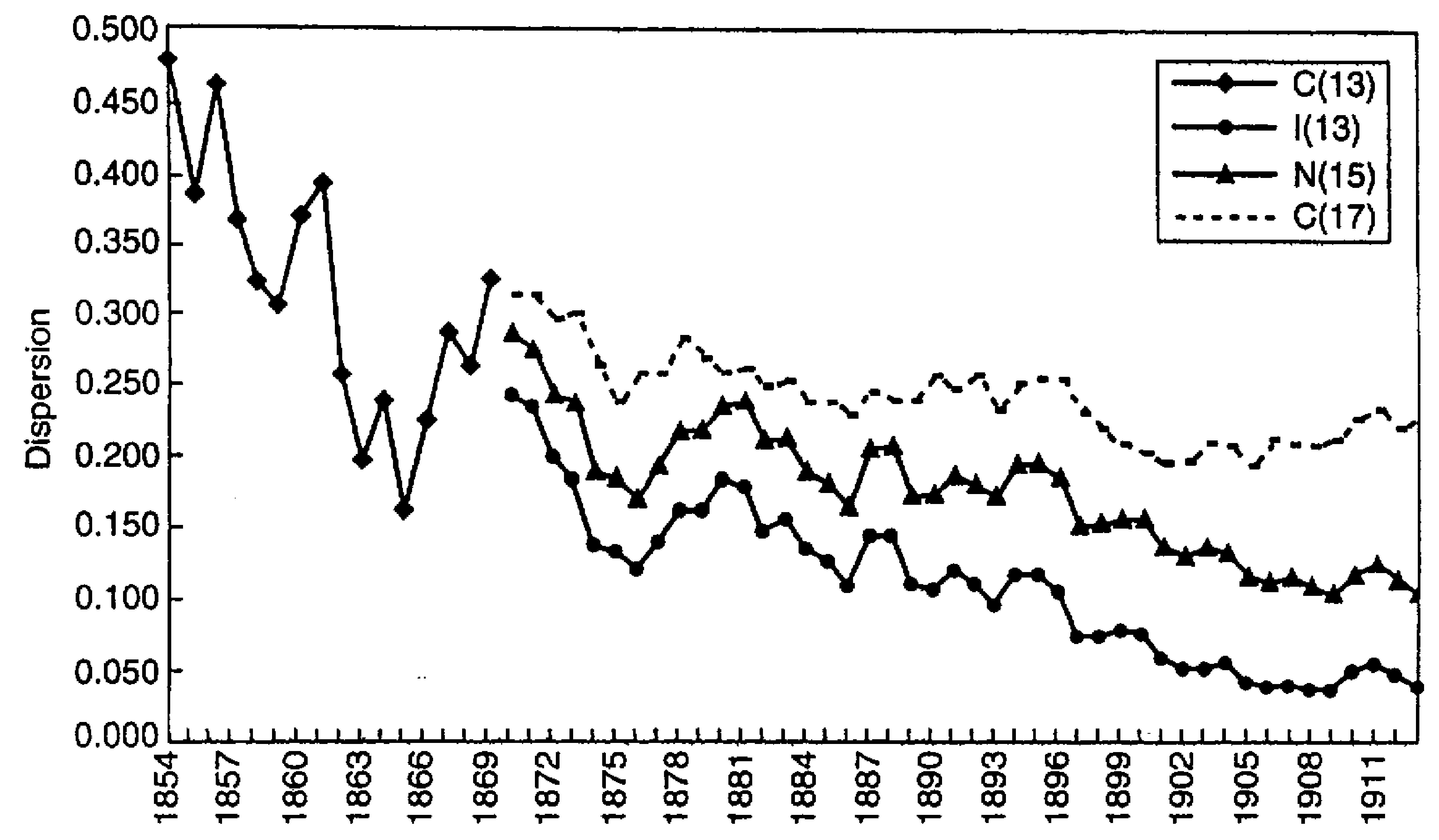

Figure 6

Real Wage Dispersion in the Atlantic Economy 1854-1913 (Source: O'Rourke and Williamson, 1999, Figure 2.2) 